\title{
Water mass distributions and transports for the 2014 GEOVIDE cruise in the North Atlantic
}

\author{
Maribel I. García-Ibáñez ${ }^{1,2}$, Fiz F. Pérez ${ }^{2}$, Pascale Lherminier ${ }^{3}$, Patricia Zunino ${ }^{3}$, Herlé Mercier ${ }^{4}$, and Paul Tréguer \\ ${ }^{1}$ Uni Research Climate, Bjerknes Centre for Climate Research, Bergen 5008, Norway \\ ${ }^{2}$ Instituto de Investigaciones Marinas (IIM, CSIC), Eduardo Cabello 6, 36208 Vigo, Spain \\ ${ }^{3}$ Ifremer, Univ. Brest, CNRS, IRD, Laboratoire d'Océanographie Physique et Spatiale (LOPS), IUEM, Plouzané, France \\ ${ }^{4}$ Centre National de la Recherche Scientifique (CNRS), Ifremer, Institut de Recherche pour le Développement (IRD), \\ Université de Bretagne Occidentale (UBO), Laboratoire d'Océanographie Physique et Spatiale (LOPS), Centre Ifremer de \\ Bretagne, 29280, Plouzané, France \\ ${ }^{5}$ Environmental Sciences Laboratory (LEMAR, UMR 6539) at the European Institute for Marine Studies (IUEM), Université \\ de Bretagne Occidentale, CNRS, 29280 Plouzané, France
}

Correspondence: Maribel I. García-Ibáñez (maribel.garcia-ibanez@uni.no)

Received: 25 August 2017 - Discussion started: 25 October 2017

Revised: 20 March 2018 - Accepted: 20 March 2018 - Published: 9 April 2018

\begin{abstract}
We present the distribution of water masses along the GEOTRACES-GA01 section during the GEOVIDE cruise, which crossed the subpolar North Atlantic Ocean and the Labrador Sea in the summer of 2014. The water mass structure resulting from an extended optimum multiparameter (eOMP) analysis provides the framework for interpreting the observed distributions of trace elements and their isotopes. Central Waters and Subpolar Mode Waters (SPMW) dominated the upper part of the GEOTRACESGA01 section. At intermediate depths, the dominant water mass was Labrador Sea Water, while the deep parts of the section were filled by Iceland-Scotland Overflow Water (ISOW) and North-East Atlantic Deep Water. We also evaluate the water mass volume transports across the 2014 OVIDE line (Portugal to Greenland section) by combining the water mass fractions resulting from the eOMP analysis with the absolute geostrophic velocity field estimated through a box inverse model. This allowed us to assess the relative contribution of each water mass to the transport across the section. Finally, we discuss the changes in the distribution and transport of water masses between the 2014 OVIDE line and the 2002-2010 mean state. At the upper and intermediate water levels, colder end-members of the water masses replaced the warmer ones in 2014 with respect to 2002-2010, in agreement with the long-term cooling of the North Atlantic Subpolar Gyre that started in the mid-2000s.
\end{abstract}

Below 2000 dbar, ISOW increased its contribution in 2014 with respect to 2002-2010, with the increase being consistent with other estimates of ISOW transports along 58-59 $\mathrm{N}$. We also observed an increase in SPMW in the East Greenland Irminger Current in 2014 with respect to 2002-2010, which supports the recent deep convection events in the Irminger Sea. From the assessment of the relative water mass contribution to the Atlantic Meridional Overturning Circulation (AMOC) across the OVIDE line, we conclude that the larger AMOC intensity in 2014 compared to the 2002-2010 mean was related to both the increase in the northward transport of Central Waters in the AMOC upper limb and to the increase in the southward flow of Irminger Basin SPMW and ISOW in the AMOC lower limb.

\section{Introduction}

The 2014 GEOVIDE cruise consisted of two hydrographic sections: the seventh repetition of the OVIDE line from Lisbon (Portugal) to Cape Farewell (Greenland), and a section across the Labrador Sea from Cape Farewell to St. John's (Canada) (Fig. 1). The GEOVIDE cruise was the major French contribution to the Global GEOTRACES programme (official GEOTRACES-GA01 section), which aimed to achieve a three-dimensional distribution of the 


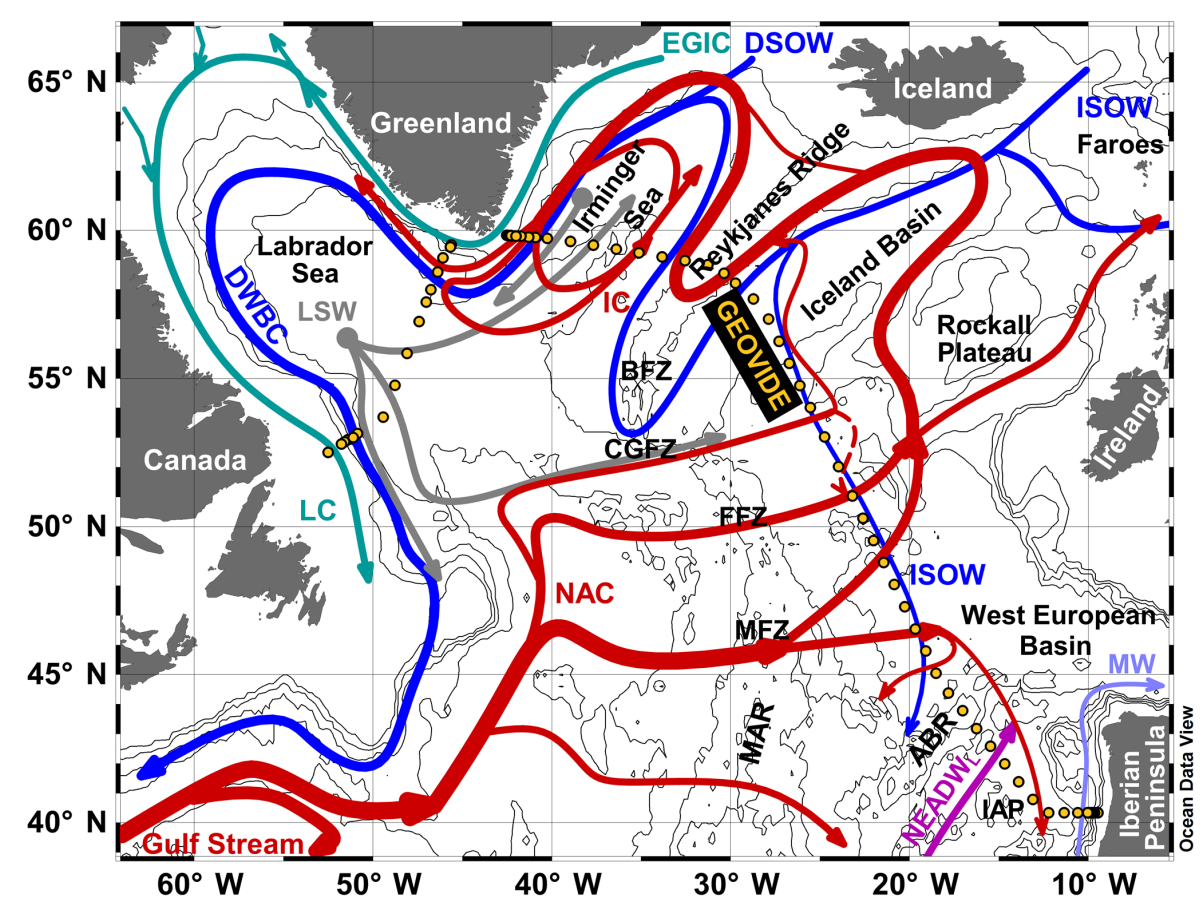

Figure 1. Schematic diagram of the large-scale circulation in the subpolar North Atlantic adapted from Daniault et al. (2016). Isobaths every 1000 dbar are represented by black contours. GEOVIDE (GEOTRACES-GA01 section) hydrographic stations are indicated by yellow dots. The main topographical features are labelled as follows: Azores-Biscay Rise (ABR), Bight Fracture Zone (BFZ), Charlie-Gibbs Fracture Zone (CGFZ), Faraday Fracture Zone (FFZ), Iberian Abyssal Plain (IAP), Maxwell Fracture Zone (MFZ) and Mid-Atlantic Ridge (MAR). The main water masses and currents are also represented: Denmark Strait Overflow Water (DSOW), Deep Western Boundary Current (DWBC), East Greenland Irminger Current (EGIC), Iceland-Scotland Overflow Water (ISOW), Irminger Current (IC), Labrador Current (LC), Labrador Sea Water (LSW), Mediterranean Water (MW), North Atlantic Current (NAC) and North-East Atlantic Deep Water lower $\left(\mathrm{NEADW}_{\mathrm{L}}\right)$.

trace elements and their isotopes (TEIs) in the global ocean (SCOR Working Group, 2007). Obtaining high-quality hydrographic and tracer measurements will enable us to trace back the origins, pathways and processes governing the observed TEI distributions.

To provide a framework for interpreting the observed TEI distributions, in this work, we qualitatively assess the water mass distribution along the 2014 GEOTRACES-GA01 section through an extended optimum multiparameter (eOMP) analysis (Karstensen and Tomczak, 1998). We extend the study performed by García-Ibáñez et al. (2015) for the 20022010 OVIDE cruises, which described the distributions and temporal variations of the main water masses along the OVIDE line, and inferred the water mass transformations within the North Atlantic Subpolar Gyre. As in that work, we also combine the water mass structure resulting from the eOMP analysis with the velocity field across the OVIDE line, obtaining water mass volume transports. The assessment of the water mass volume transports based on dilutions of "pure" (OMP-based) water masses provides insights into the circulation features that are particularly useful for areas of complex currents and water mass transformation, as in the subpolar North Atlantic (SPNA). Finally, we compare the water mass distribution and transport of the 2014 OVIDE line with the average water mass distribution and transport of the 2002-2010 OVIDE cruises (García-Ibáñez et al., 2015) and link the observed changes to major changes in the formation and circulation of water masses in the SPNA.

\section{Data and methods}

\subsection{The hydrographic data}

The GEOVIDE cruise (GEOTRACES-GA01 section) was conducted in June-July 2014 and consisted of 78 stations along the eastern SPNA and the Labrador Sea (Fig. 1). During the first cast in each station, a classical rosette equipped with 22 Niskin bottles and CTD SBE-911 equipped with a dissolved oxygen sensor SBE-43 was deployed. This first station cast was used as a reference for the physical and chemical characterization of water masses. Discrete sampling for oxygen, nutrients and salinity was performed at all 78 stations. Nutrient concentrations (nitrate and silicic acid) were measured by the continuous flow analyser, giving the concentration values in $\mu \mathrm{M}\left(\mu \mathrm{mol} \mathrm{L} \mathrm{L}^{-1}\right)$. We transformed measured nutrient concentrations in $\mu \mathrm{M}$ to $\mu \mathrm{mol} \mathrm{kg}^{-1}$ by dividing by 


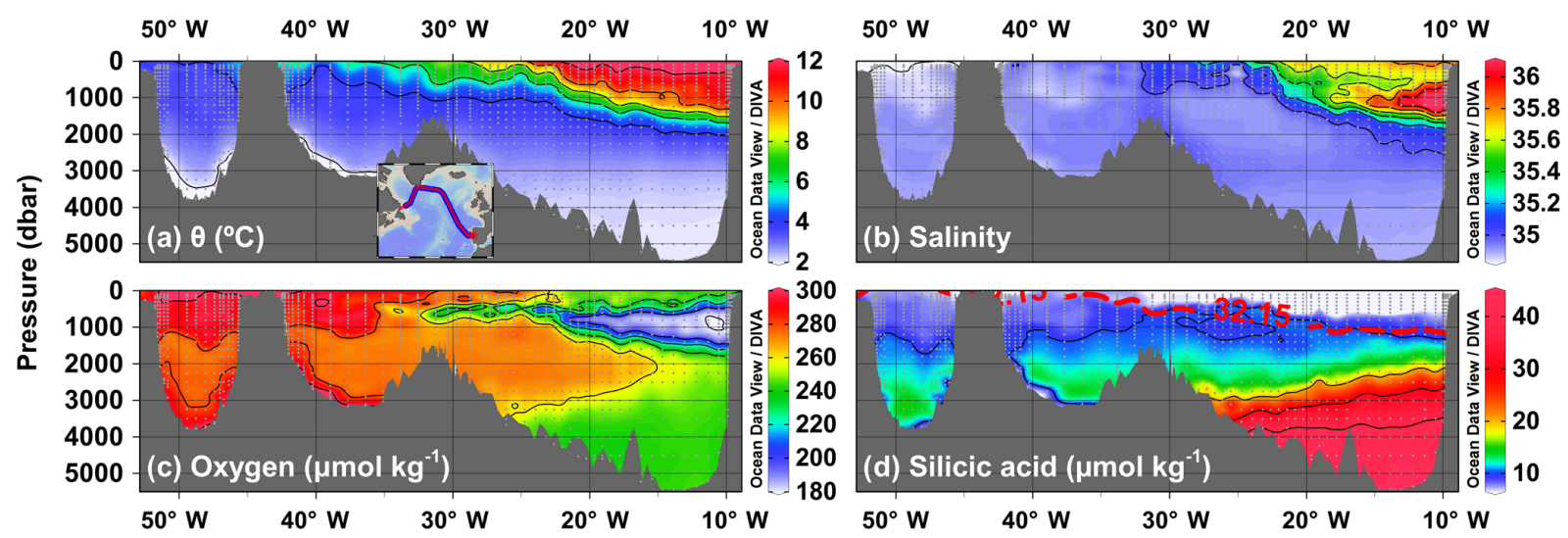

Figure 2. (a) Potential temperature $\left(\theta\right.$, in ${ }^{\circ} \mathrm{C}$ ), (b) salinity, (c) oxygen (in $\mu \mathrm{mol} \mathrm{kg}^{-1}$ ), and (d) silicic acid (in $\mu \mathrm{mol} \mathrm{kg}-1$ ) along 2014 GEOVIDE cruise (GEOTRACES-GA01 section, inset in subplot a), from Portugal (right) to Canada (left). Sample locations appear as grey dots. The dashed horizontal red line in subplot (d) represents the isopycnal $\sigma_{1}=32.15 \mathrm{~kg} \mathrm{~m}^{-3}$ (where $\sigma_{1}$ is potential density referenced to 1000 dbar), which marks the limit between the upper and lower limbs of the Atlantic Meridional Overturning Circulation (AMOC) at the GEOTRACES-GA01 section (Zunino et al., 2017).

the density of the sample at $20^{\circ} \mathrm{C}$ (measurement temperature). Accuracies were $0.001^{\circ} \mathrm{C}$ for temperature, 0.002 for salinity, $2 \mu \mathrm{mol} \mathrm{kg}^{-1}$ for oxygen and $0.1 \mu \mathrm{mol} \mathrm{kg}{ }^{-1}$ for nutrients. Upper water velocity was continuously measured with two ship-mounted acoustic Doppler current profilers (ADCPs; Ocean Surveyors).

For further reference, the vertical sections of potential temperature $(\theta)$, salinity, oxygen and silicic acid are shown in Fig. 2.

\subsection{Hydrographic features and general circulation}

The 2014 GEOTRACES-GA01 section crossed regions of water mass transformation and deep convection leading to water mass formation (e.g. Sarafanov et al., 2012; GarcíaIbáñez et al., 2015; Yashayaev and Loder, 2017). The North Atlantic Current (NAC) carries warm and saline subtropical waters northwards, towards the north-eastern Atlantic Ocean (Fig. 1). Air-sea interaction progressively reduces the temperature of the Central Waters transported by the NAC, being ultimately transformed into Subpolar Mode Water (SPMW) (McCartney and Talley, 1982; Tsuchiya et al., 1992). The continuous air-sea interaction along the NAC path leads to a continuous transition of varieties of Central Waters and SPMWs (McCartney and Talley, 1982; Pollard et al., 1996; Brambilla and Talley, 2008; de Boisséson et al., 2012). The last stage of the transformation of SPMW is the Labrador Sea Water (LSW), which is formed in the Labrador and Irminger seas (e.g. Pickart et al., 2003; de Jong and de Steur, 2016; Fröb et al., 2016; Piron et al., 2017). After its formation, LSW enters the Deep Western Boundary Current (DWBC) (Bersch et al., 2007) (Fig. 1), where it joins the Denmark Strait Overflow Water (DSOW) and the Iceland-Scotland Overflow Water (ISOW) (Rudels et al., 2002; Tanhua et al., 2008). DSOW forms after the deep waters of the Nordic Seas overflow the Greenland-Iceland sill and entrain Atlantic waters (SPMW and LSW) (Read, 2000; Yashayaev and Dickson, 2008). Cascading events of Polar Intermediate Water (PIW) also affect DSOW in the Irminger Sea (e.g. Pickart et al., 2005; Falina et al., 2012; Jochumsen et al., 2015). ISOW forms after the Norwegian Sea waters overflow the IcelandScotland sills and entrain SPMW and LSW (van Aken and de Boer, 1995; Dickson et al., 2002; Fogelqvist et al., 2003). Then, ISOW flows southwards in the Iceland Basin, mainly along the eastern flank of the Reykjanes Ridge. Through the journey of ISOW in the Iceland Basin, entrainment events lead to the formation of the North-East Atlantic Deep Water (NEADW) (van Aken, 2000). NEADW recirculates in the West European Basin (Fig. 1) and mixes with the surrounding waters, including the Antarctic Bottom Water (van Aken and Becker, 1996), which results in thermohaline properties of NEADW that can be approximated as a line (Saunders, 1986; Mantyla, 1994). The waters of the GEOTRACESGA01 section are also influenced by the saline Mediterranean Water (MW), and the relatively fresh Subarctic Intermediate Water (SAIW). MW enters the North Atlantic from the Mediterranean Sea after overflowing the Strait of Gibraltar (Ambar and Howe, 1979; Baringer and Price, 1997). SAIW originates in the western boundary of the subpolar gyre, i.e. the Labrador Current (Fig. 1) (Arhan, 1990), by mixing between the warm saline waters of the NAC with the cold and fresher LSW (Iselin, 1936; Arhan, 1990; Read, 2000). The thermohaline properties of SAIW vary along its pathway towards the West European Basin, becoming saltier and warmer (Harvey and Arhan, 1988; Pollard et al., 2004).

The above-described water mass formation processes occurring in the SPNA lead to the ventilation and renewal of the intermediate and deep ocean, and are the start process of the Atlantic Meridional Overturning Circulation (AMOC) (Kuhlbrodt et al., 2007; Rhein et al., 2011; Sarafanov et al., 
2012). The AMOC consists of two limbs: a warm northwardflowing upper limb, and a colder southward-flowing lower limb. For the OVIDE line, the upper limb of the AMOC is constituted by the Central Waters, the SPMW of the Iceland Basin, SAIW and MW, while the AMOC lower limb is constituted by the SPMW of the Irminger Sea (IrSPMW), PIW, LSW, ISOW, DSOW and NEADW (García-Ibáñez et al., 2015).

\subsection{Extended optimum multiparameter (eOMP) analysis}

To solve the complex water mass structure of the SPNA, we used an optimum multiparameter (OMP) analysis (Tomczak and Large, 1989). This technique has previously been used to describe in detail the origin, pathways and transformation of the main water masses in the SPNA (Tanhua et al., 2005; Álvarez et al., 2004, 2005; García-Ibáñez et al., 2015). Briefly, OMP analyses consider the properties of a given water sample to be the result of linear combinations of a finite number of water masses represented by the so-called source water types (SWTs) (Tomczak, 1999). In this study, SWTs were characterized by $\theta$, salinity, oxygen, silicic acid and nitrate (Table 1). Once the SWTs and their physical and chemical properties are defined, the OMP analysis solves the mixing between SWTs by a least-square method constrained to be positive definite, giving the fractions of each SWT $\left(X_{i}\right)$ in each water sample:

$d=\mathbf{G} * X_{i}+r$,

where $d$ is the observed property in a water sample, $\mathbf{G}$ is the matrix containing the properties defining the SWTs, $X_{i}$ is the relative contributions of each SWT to the sample, and $r$ is the residual. An additional constraint is mass conservation, which ensures the contributions of all the SWTs sum to $100 \%$ :

$\sum X_{i}=1+r$

In this study, we solved an extended OMP (eOMP) analysis (Karstensen and Tomczak, 1998), which accounts for the non-conservative behaviour of oxygen and nutrients by using Redfield-like stoichiometric ratios $(R)$ :

$d=\mathbf{G} * X_{i}+\Delta \mathrm{O}_{2_{\mathrm{bio}}} / R+r$,

where $R$ is 12 for silicic acid (Perez et al., 1993; Castro et al., 1998), and 10.5 for nitrate (Takahashi et al., 1985; Anderson and Sarmiento, 1994). The $\Delta \mathrm{O}_{2_{\text {bio }}}$ term accounts for the changes in oxygen due to the synthesis and/or remineralisation of the organic matter.

To be able to compare the resulting water mass distribution and transport for OVIDE 2014 with the average of OVIDE 2002-2010 (García-Ibáñez et al., 2015), we used the same eOMP set-up as in García-Ibáñez et al. (2015), but with readjusted thermohaline properties for LSW and
ISOW to better represent these water masses in the 2010s (e.g. Hansen et al., 2016; Yashayaev and Loder, 2017). We used 14 SWTs to solve the water mass structure along the GEOTRACES-GA01 section (Table 1, Fig. 3). The upper waters of the GEOTRACES-GA01 section were characterized by Central Waters and SPMW. The thermohaline range of the Central Waters was solved by defining two SWTs that coincide with extremes of the $\theta-S$ line defining the East North Atlantic Central Waters (ENACW), the predominant variety of the North Atlantic Central Waters to the east of the Mid-Atlantic Ridge (Iselin, 1936): ENACW of $16^{\circ} \mathrm{C}\left(\mathrm{ENACW}_{16}\right)$, whose $\theta-\mathrm{S}$ characteristics match those from the warmer central waters of Pollard et al. (1996), and ENACW of $12^{\circ} \mathrm{C}\left(\mathrm{ENACW}_{12}\right)$, which represents the upper limit of ENACW defined by Harvey (1982). The change in temperature of SPMW along the NAC path cannot be accounted by the OMP analysis, since it is the result of airsea interaction (e.g. McCartney and Talley, 1982; Brambilla and Talley, 2008). This problem was solved by defining three SWTs to characterize SPMW: SPMW of $8^{\circ} \mathrm{C}\left(\mathrm{SPMW}_{8}\right)$, SPMW of $7^{\circ} \mathrm{C}\left(\mathrm{SPMW}_{7}\right)$ and SPMW of the Irminger Basin (IrSPMW). $\mathrm{SPMW}_{7}$ and $\mathrm{SPMW}_{8}$ characterize the thermohaline range of SPMW in the Iceland Basin, with the $\theta-\mathrm{S}$ of $\mathrm{SPMW}_{8}$ being representative of that formed within the Iceland Basin (Brambilla and Talley, 2008), and the $\theta-S$ of $\mathrm{SPMW}_{7}$ to that found over the eastern flank of the Reykjanes Ridge (Thierry et al., 2008). The $\theta-S$ of IrSPMW characterize SPMW found in the Irminger Sea (Brambilla and Talley, 2008), and are close to those of the Irminger Sea Water (Krauss, 1995). The intermediate waters of the GEOTRACES-GA01 section were characterized by LSW, MW and SAIW. The thermohaline properties of LSW were chosen from the thermohaline properties of LSW formed in 2008 (LSW 2008 ; Kieke and Yashayaev, 2015; Yashayaev and Loder, 2009, 2017), which, according to the transit times proposed by Yashayaev et al. (2007), would have reached the Irminger and Iceland basins by 2014. The properties of MW were taken from Wüst and Defant (1936) near Cape St. Vicente, where MW has its $\theta-S$ characteristics established after overflowing the Strait of Gibraltar (Ambar and Howe, 1979; Baringer and Price, 1997). The thermohaline range of SAIW $\left(4-7^{\circ} \mathrm{C}\right.$ and $\left.S<34.9\right)$ was represented by two SWTs: SAIW of $6{ }^{\circ} \mathrm{C}\left(\mathrm{SAIW}_{6}\right)$ and SAIW of $4{ }^{\circ} \mathrm{C}\left(\mathrm{SAIW}_{4}\right)$, following the descriptions of Bubnov (1968) and Harvey and Arhan (1988). Finally, the deep waters of the GEOTRACESGA01 section were characterized by DSOW, ISOW and NEADW. The thermohaline properties of ISOW were defined as the ISOW properties after crossed the IcelandScotland sills defined by van Aken and Becker (1996), and these properties were readjusted by increasing ISOW temperature and salinity by $0.1^{\circ} \mathrm{C}$ and 0.01 , respectively, according to the observed changes in the overflow properties since 2002 (Hansen et al., 2016). The thermohaline characteristics chosen for DSOW were selected from those found by Tanhua et al. (2005) downstream of the Greenland-Iceland sill. 
Table 1. Properties characterizing the source water types $\left(\mathrm{SWTs}^{\mathrm{a}}\right)$ considered in this study with their corresponding standard deviations ${ }^{\mathrm{b}}$. The square of correlation coefficients $\left(R^{2}\right)$ between the observed and estimated properties are also given, together with the standard deviation of the residuals (SDR) and the SDR $/ \varepsilon$ ratios from the data below 400 dbar. The $\varepsilon$ (standard deviation of the water sample properties) used to compute the SDR $/ \varepsilon$ ratios are listed in Table S1. The last column accounts for the uncertainties in the SWT contributions.

\begin{tabular}{|c|c|c|c|c|c|c|}
\hline & $\begin{array}{r}\Theta \\
\left({ }^{\circ} \mathrm{C}\right)\end{array}$ & S & $\begin{array}{r}\mathrm{O}_{2}^{0} \\
(\mu \mathrm{mol} \mathrm{kg}\end{array}$ & $\begin{array}{r}\mathrm{Si}\left(\mathrm{OH}_{4}\right)^{0} \\
\left(\mu \mathrm{mol} \mathrm{kg}{ }^{-1}\right)\end{array}$ & $\begin{array}{r}\mathrm{NO}_{3}^{0} \\
\left(\mu \mathrm{mol} \mathrm{kg}{ }^{-1}\right)\end{array}$ & Uncertainty \\
\hline ENACW $_{16}$ & $16.0 \pm 0.6$ & $36.20 \pm 0.06$ & $246 \pm 7$ & $1.87 \pm 0.12$ & $0.00 \pm 0.15$ & $9 \%$ \\
\hline ENACW $_{12}$ & $12.3 \pm 0.6$ & $35.66 \pm 0.06$ & $251 \pm 8$ & $1.3 \pm 0.9$ & $8.0 \pm 1.1$ & $10 \%$ \\
\hline $\mathrm{SPMW}_{8}$ & $8.0 \pm 0.6$ & $35.23 \pm 0.06$ & $289 \pm 9$ & $2.7 \pm 1.9$ & $11.4 \pm 1.3$ & $11 \%$ \\
\hline $\mathrm{SPMW}_{7}$ & $7.1 \pm 0.6$ & $35.16 \pm 0.06$ & $280 \pm 8$ & $5.20 \pm 0.15$ & $12.83 \pm 0.15$ & $6 \%$ \\
\hline IrSPMW & $5.0 \pm 0.6$ & $35.01 \pm 0.06$ & $310 \pm 9$ & $5.9 \pm 0.4$ & $14.1 \pm 0.4$ & $12 \%$ \\
\hline LSW & $3.40 \pm 0.4$ & $34.86 \pm 0.01$ & $307 \pm 9$ & $6.9 \pm 0.7$ & $14.8 \pm 0.7$ & $10 \%$ \\
\hline SAIW $_{6}$ & $6.0 \pm 0.5$ & $34.70 \pm 0.03$ & $297 \pm 9$ & $6.0 \pm 2.4$ & $13.3 \pm 1.2$ & $9 \%$ \\
\hline $\mathrm{SAIW}_{4}$ & $4.5 \pm 0.5$ & $34.80 \pm 0.03$ & $290 \pm 9$ & $0.0 \pm 2.4$ & $0.0 \pm 1.2$ & $3 \%$ \\
\hline MW & $11.7 \pm 0.2$ & $36.50 \pm 0.07$ & $190 \pm 6$ & $6.30 \pm 0.15$ & $13.2 \pm 0.2$ & $2 \%$ \\
\hline ISOW & $2.7 \pm 0.1$ & $35.00 \pm 0.02$ & $294 \pm 9$ & $11.8 \pm 0.9$ & $14.0 \pm 0.6$ & $9 \%$ \\
\hline DSOW & $1.30 \pm 0.2$ & $34.905 \pm 0.01$ & $314 \pm 9$ & $7.0 \pm 0.5$ & $12.9 \pm 0.8$ & $7 \%$ \\
\hline PIW & $0.0 \pm 0.2$ & $34.65 \pm 0.03$ & $320 \pm 10$ & $8.4 \pm 2.5$ & $13.4 \pm 1.2$ & $9 \%$ \\
\hline $\mathrm{NEADW}_{U}$ & $2.5 \pm 0.5$ & $34.940 \pm 0.07$ & $274 \pm 8$ & $29.4 \pm 0.6$ & $18.1 \pm 0.5$ & $\mathrm{n} / \mathrm{a}^{\mathrm{c}}$ \\
\hline $\mathrm{NEADW}_{\mathrm{L}}$ & $1.98 \pm 0.03$ & $34.895 \pm 0.003$ & $252 \pm 8$ & $48.0 \pm 0.3$ & $22.0 \pm 0.5$ & $3 \%$ \\
\hline$R^{2}$ & 0.9999 & 0.9984 & 0.9939 & 0.9978 & 0.9941 & \\
\hline SDR & 0.009 & 0.005 & 2 & 0.4 & 0.2 & \\
\hline $\mathrm{SDR} / \varepsilon$ & 2 & 2 & 2 & 1 & 1 & \\
\hline
\end{tabular}

${ }^{\mathrm{a}} \mathrm{ENACW}_{16}$ and $\mathrm{ENACW}_{12}=$ East North Atlantic Central Water of 16 and $12{ }^{\circ} \mathrm{C}$, respectively; $\mathrm{SPMW}_{8}, \mathrm{SPMW}_{7}$ and $\mathrm{IrSPMW}=\mathrm{Subpolar}$

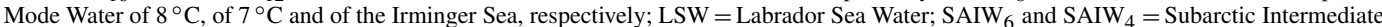
Water of 6 and $4{ }^{\circ} \mathrm{C}$, respectively; MW = Mediterranean Water; ISOW = Iceland-Scotland Overflow Water; DSOW $=$ Denmark Strait Overflow Water; PIW $=$ Polar Intermediate Water; and $\mathrm{NEADW}_{\mathrm{U}}$ and $\mathrm{NEADW}_{\mathrm{L}}=$ North-East Atlantic Deep Water upper and lower, respectively. ${ }^{b}$ The standard deviation of the properties of the SWTs were obtained following the method described in Text S1 in the

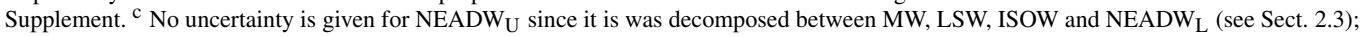
n/a: not applicable.

We also included PIW in the analysis to take into account the dense shelf water intrusions into DSOW. The thermohaline characteristics selected for PIW are in agreement with those proposed by Malmberg (1972) and Rudels et al. (2002). NEADW was modelled by the definition of two SWTs equal to the end-points of the line defining the thermohaline properties of NEADW in the West European Basin (Saunders, 1986; Mantyla, 1994; Castro et al., 1998): upper NEADW $\left(\mathrm{NEADW}_{\mathrm{U}}\right)$ and lower NEADW $\left(\mathrm{NEADW}_{\mathrm{L}}\right)$.

In order to solve an over-determined system of linear mixing equations (Eqs. 2 and 3), a maximum of four SWTs can be considered simultaneously: one Eq. (3) for each variable defining the SWTs (i.e. 5) and the mass conservation equation (Eq. 3), and five unknowns - four $X_{i}$ values and $\Delta \mathrm{O}_{2_{\text {bio }}}$. This inconvenience was solved by organizing the SWTs into 11 subsets or mixing groups (Fig. 3c), based on the characteristics and dynamics of the SWTs in the SPNA. The mixing groups are vertically and horizontally sequenced, and share at least one SWT with the adjacent mixing groups to ensure water mass continuity (for more details about the eOMP setup see García-Ibáñez et al., 2015). After obtaining the $X_{i}$ values for each water sample, the $X_{i}$ of $\mathrm{NEADW}_{\mathrm{U}}$ was decomposed into $1 \%$ of MW, $13 \%$ of LSW, $36 \%$ of ISOW and
$50 \%$ of $\mathrm{NEADW}_{\mathrm{L}}$ (van Aken, 2000; Álvarez et al., 2004; Carracedo et al., 2012; García-Ibáñez et al., 2015).

An important assumption of the methodology is that the physical and chemical characteristics of the SWTs are considered time-invariant and equally affected by mixing; hence, changes in the properties of the water masses over time are reflected through water mass redistributions. The first $75 \mathrm{dbar}$, where non-conservative behaviour of temperature and salinity is expected, were excluded from the analysis to avoid changes in water mass properties due to air-sea interaction. Water samples with salinity lower than 34.7 were also excluded from the analysis to avoid the influence of high percentages of fresh water (Daniault et al., 2011).

We tested the robustness of the methodology through a Monte Carlo simulation (Tanhua et al., 2005), where the physical and chemical properties of both each SWT and each water sample were randomly perturbed within the standard deviation of each parameter (Table 1; see also Text S1 and Table S1 in the Supplement). This allowed an assessment of the sensitivity of the eOMP analysis to potential measurement errors and temporal variations in the physical and chemical properties that define the SWTs (Leffanue and Tomczak, 2004). A hundred Monte Carlo simulations were performed and the eOMP equation system was solved for 

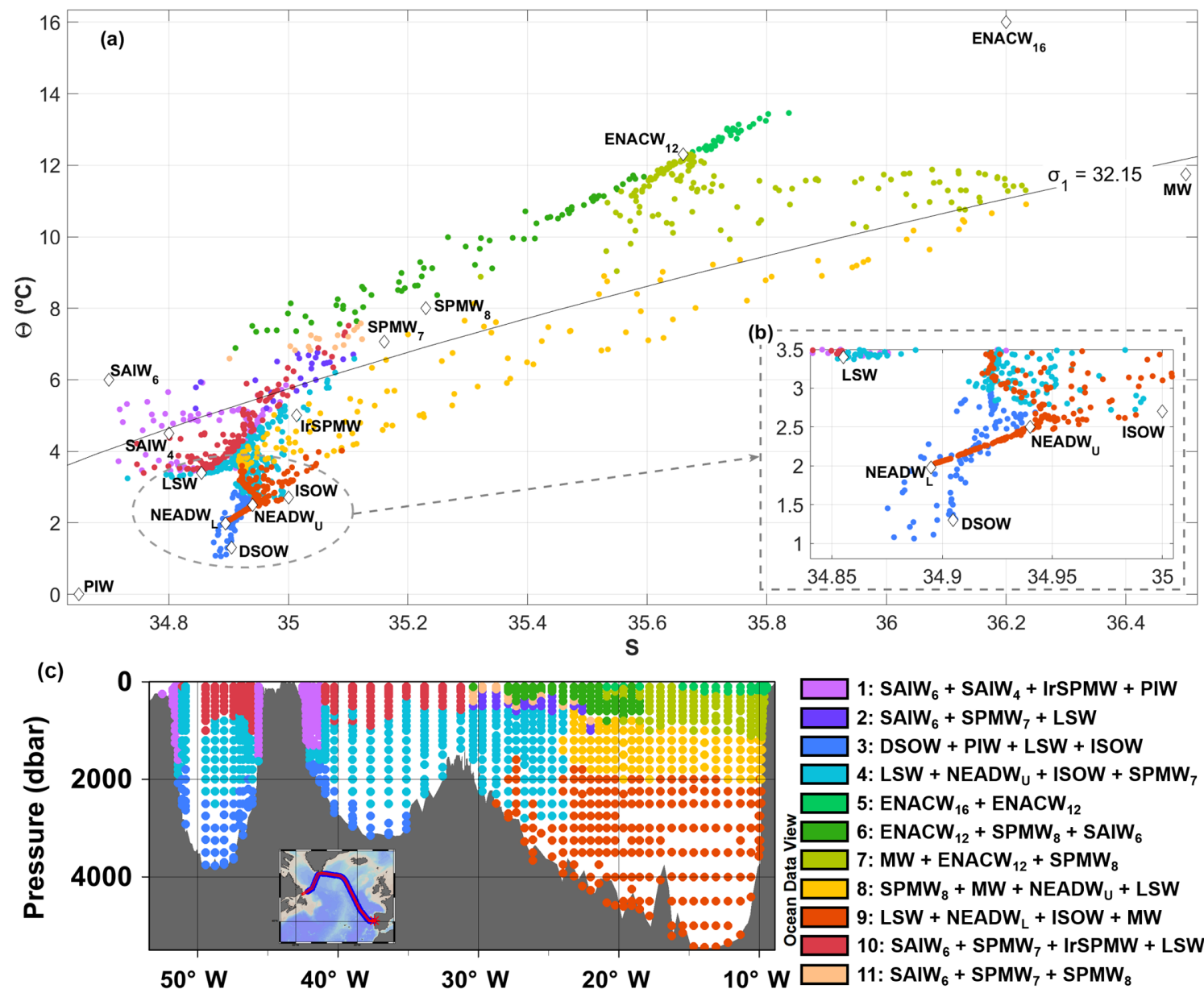

Figure 3. (a) Potential temperature $(\theta)$-salinity (S) diagram including the source water types (SWTs; Table 1) and (b) zoomed for deep waters. The isopycnal $\sigma_{1}=32.15 \mathrm{~kg} \mathrm{~m}^{-3}$ delimiting the upper and lower limbs of the AMOC at the GEOTRACES-GA01 section is also plotted. Colour coding represents the mixing groups (legend on c), i.e. subsets of SWTs susceptible of mixing together. (c) Distribution of the mixing groups along the GEOTRACES-GA01 section (inset).

each of them. The average standard deviation of the $X_{i}$ values (last column in Table 1) is lower than $12 \%$, which indicates that the methodology is robust. Additionally, our eOMP analysis is consistent since its residuals ( $r$ in Eq. 3) lack a tendency with depth (Fig. S1 in the Supplement), with the standard deviations of the residuals being slightly higher than the measurement errors (Table 1). Besides, the ability of our eOMP analysis to reproduce the measured values is given as the correlation coefficient $\left(R^{2}\right.$, Table 1$)$ between the measured values (water samples) and the expected values for the SWT mixing (values of the properties of each water sample obtained by when substituting $X_{i}$ values in Eq. 3). The $R^{2}$ values are higher than 0.993 , which again indicates the reliability of our eOMP analysis.

\section{Water mass distribution for 2014}

The water mass distribution for the 2014 GEOTRACESGA01 section (Fig. 4) was obtained through an eOMP analysis (Sect. 2.3).

The Central Waters (ENACW $16+\mathrm{ENACW}_{12}$ ) occupy the upper eastern part of the 2014 GEOTRACES-GA01 section from the Iberian Peninsula until the Reykjanes Ridge (Fig. $4 \mathrm{a}, \mathrm{b}$ ), with $\mathrm{ENACW}_{12}$ being the dominant one. The contribution of ENACW 12 exceeds $90 \%$ in the upper 500 dbar in the Iberian Abyssal Plain, following the maximum in $\theta$ and the minimum in silicic acid (Fig. 2a, d). The distribution of the Central Waters is associated with the NAC, which is associated with the thermohaline front (Fig. 2a, b) delimiting ENACW 12 . The westward extension of ENACW 12 reflects its cyclonic circulation in the Iceland Basin and its southward flow over the eastern flank of the Reykjanes Ridge (Read, 2000; Pollard et al., 2004). 


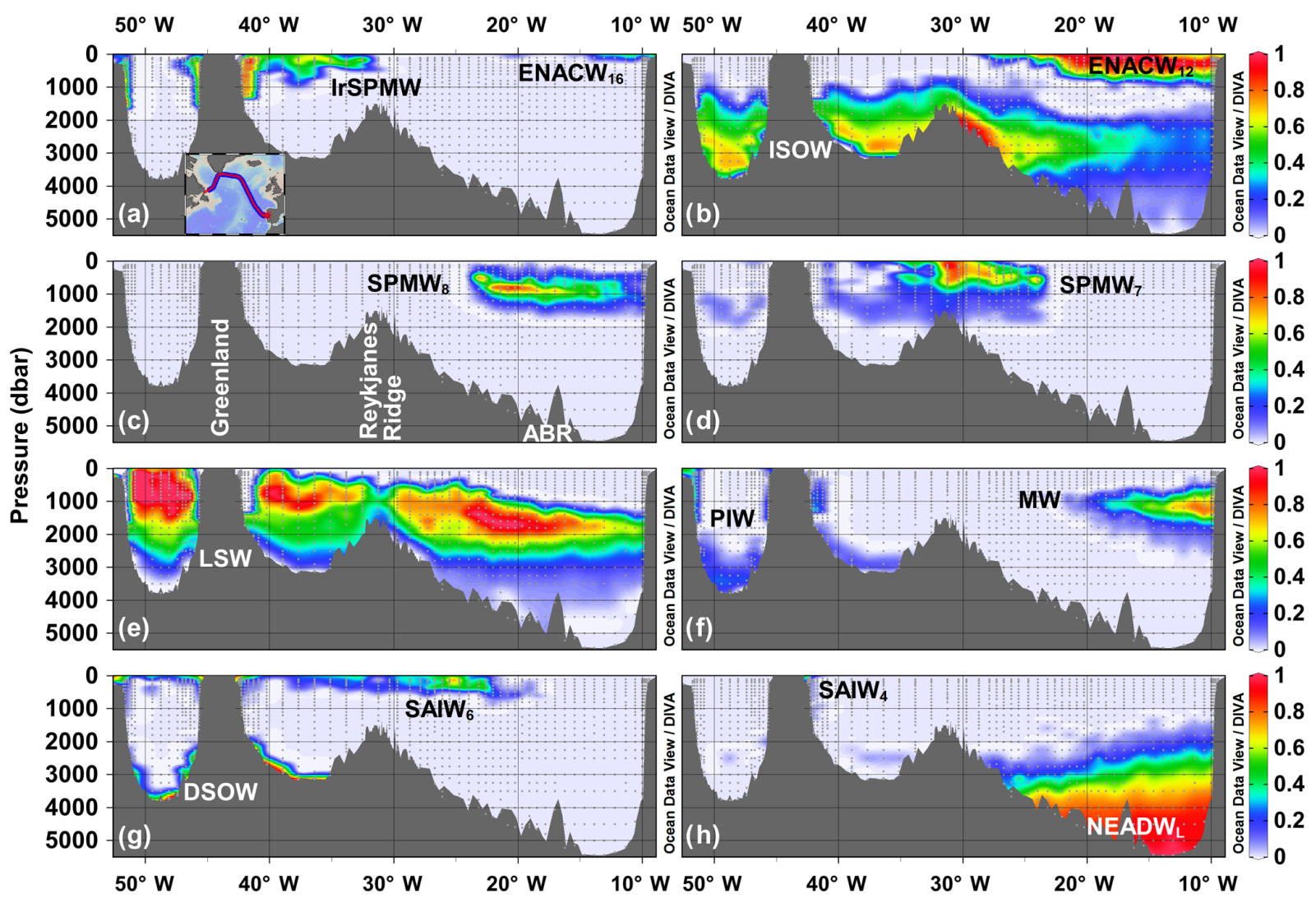

Figure 4. Water mass distribution resulting from the eOMP analysis for the 2014 GEOVIDE cruise (GEOTRACES-GA01 section, inset in subplot a), from Portugal (right) to Canada (left). Sample locations appear as grey dots. ABR refers to Azores-Biscay Rise. Consult Table 1 for water mass acronyms.

The cooler end-member of the Central Waters, $\mathrm{SPMW}_{8}$, extends below $\mathrm{ENACW}_{12}$ (Fig. 4c). Air-sea interaction processes along the NAC transforms both $\mathrm{ENACW}_{12}$ and SPMW $_{8}$ into SPMW 7 (Thierry et al., 2008; García-Ibáñez et al., 2015), which dominates the upper $1500 \mathrm{dbar}$ of the Iceland Basin and above the Reykjanes Ridge (Fig. 4d). The distribution of $\mathrm{SPMW}_{7}$ reflects the circulation of the NAC around the Reykjanes Ridge, from the Iceland Basin to the Irminger Sea (Brambilla and Talley, 2008). Further transformation of $\mathrm{SPMW}_{7}$ through air-sea interaction along the path of the NAC leads to the formation of IrSPMW in the Irminger Sea (Brambilla and Talley, 2008). The main core of IrSPMW is on the Greenland slope, from where it extends eastwards until the Reykjanes Ridge (Fig. 4a). This distribution could indicate that the major region of formation of IrSPMW is the north-west of the Irminger Sea (Brambilla and Talley, 2008), from where the East Greenland Irminger Current (EGIC) (Fig. 1) would transport it until the GEOTRACES-GA01 section and then to the Labrador Sea. Once in the Labrador Sea, IrSPMW could act as a precursor for the upper LSW (Pickart et al., 2003).

SAIW $\left(\mathrm{SAIW}_{6}+\mathrm{SAIW}_{4}\right)$ extends along the upper western part of the 2014 GEOTRACES-GA01 section, from the
Labrador Sea to $20^{\circ} \mathrm{W}$ (Fig. $4 \mathrm{~g}, \mathrm{~h}$ ), with $\mathrm{SAIW}_{6}$ being the main end-member and $\mathrm{SAIW}_{4}$ only found over the Greenland Slope with less than $35 \%$ of contribution (average of $11 \pm 7 \% ; n=55$ ). The maximum contributions of SAIW are in the surface layer of the Labrador Sea, over the Greenland Slope and in the first $1000 \mathrm{dbar}$ on the eastern side of the Reykjanes Ridge. This distribution reflects the formation and circulation of SAIW. After its formation in the Labrador Current (Arhan, 1990), SAIW subducts below the NAC that transports it to the Iceland Basin (Bubnov, 1968; Arhan, 1990; Read, 2000), where it mixes with SPMWs and Central Waters.

The dominant water mass in the 2014 GEOTRACESGA01 section is LSW (Fig. 4e), which extends along the whole section. The highest contribution of LSW is in the Labrador Sea, with LSW concentrations reaching $100 \%$. LSW fills the Labrador Sea from the surface almost to the seafloor, with the higher concentrations found in the upper $1500 \mathrm{dbar}$. The distribution of LSW in the Labrador Sea indicates recent ventilation (Kieke and Yashayaev, 2015), which is also found in the Irminger Sea (de Jong and de Steur, 2016), where high concentrations of LSW extend from surface to about $1200 \mathrm{dbar}$. The high oxygen concentration 
found in the upper $\sim 1500 \mathrm{dbar}$ in both basins (Fig. 2c) corroborate the recent ventilation of the LSW layer in the Labrador and Irminger Seas. The distribution of LSW in the Labrador Sea extending deeper than 2000 dbar reflects the diapycnal mixing with ISOW (Lauderdale et al., 2008) and/or the entrainment of LSW in the ISOW layer all along the subpolar gyre. The LSW concentration in the Irminger Sea is lower than in the Labrador Sea, with the upper 1000 dbar of the Irminger Sea being dominated by a mixture of IrSPMW and LSW. The recent events of deep convection observed in the Irminger Sea led to the formation of LSW-like water in the Irminger Sea (de Jong and de Steur, 2016), with characteristics in between the end-members of IrSPMW and LSW. High LSW concentrations are also found in the West European Basin between 1000 and $3000 \mathrm{dbar}$. The decrease in the contribution of LSW found over the Reykjanes Ridge, where waters are a mixture between $\mathrm{SPMW}_{7}, \mathrm{LSW}$ and ISOW, suggests strong mixing around and over the Reykjanes Ridge (Ferron et al., 2014). This strong mixing is also observed in the $\theta$ and salinity distributions (Fig. 2a, b) by a deepening of the isotherm of $6{ }^{\circ} \mathrm{C}$ and the isohaline of 35 . Some authors refer the admixture of Atlantic waters and ISOW found around and over the Reykjanes Ridge as Icelandic Slope Water (e.g. Yashayaev et al., 2007), which in our study is represented by mixing group 4 SPMW $_{7}, \mathrm{LSW}$, ISOW and NEADW Fig. 3c).

The relatively high salinity and low oxygen concentration centred at $1500 \mathrm{dbar}$ in the West European Basin (Fig. 2b, c) are linked to MW (Fig. 4f). MW intersects the GEOTRACES-GA01 section over the Iberian shelf, between 500 and $2000 \mathrm{dbar}$, and spreads westwards until $20^{\circ} \mathrm{W}$. This westward extension may result from meddy transport (Arhan and King, 1995; Mazé et al., 1997) or may be associated with the Azores countercurrent (Carracedo et al., 2014).

The western part of the 2014 GEOTRACES-GA01 section (west of $20^{\circ} \mathrm{W}$ ) below $2000 \mathrm{dbar}$ is dominated by ISOW (Fig. 4b). The main core of ISOW is located on the eastern flank of the Reykjanes Ridge, reaching percentages greater than $90 \%$. From this region, ISOW extends eastwards into the West European Basin, where it is progressively eroded

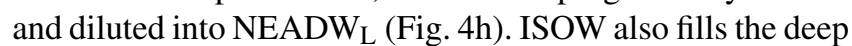
areas of the Irminger and Labrador Seas, with concentrations greater than $50 \%$. This distribution of ISOW is consistent with its circulation from the Iceland-Scotland sills, across the Iceland Basin along the eastern flank of the Reykjanes Ridge, crossing the Charlie-Gibbs Fracture Zone (CGFZ) (Dickson and Brown, 1994; Saunders, 2001), flowing cyclonically in the Irminger Sea (Sarafanov et al., 2012) and joining the DWBC (e.g. Price and Baringer, 1994; Rudels et al., 2002; Tanhua et al., 2008), and then flowing cyclonically in the Labrador Sea (Xu et al., 2010). The eastward extension of ISOW into the West European Basin may result from a fraction of ISOW bypassing the CGFZ (Fig. 1), as reported in previous studies (e.g. Fleischmann et al., 2001; LeBel et al., 2008; Xu et al., 2010; Zou et al., 2017).
The bottom areas of the Labrador and Irminger Seas are occupied by DSOW (Fig. 4g). The DSOW distribution is coincident with a minimum of $\theta\left(<2{ }^{\circ} \mathrm{C}\right)$, a maximum of oxygen and a relative minimum of silicic acid (Fig. 2a, c, d). The DSOW distribution supports the circulation scheme for DSOW, which, after its overflow formation on the Greenland-Iceland sill, joins the DWBC, and then continues flowing within that current around the Labrador Sea. Percentages of up to $25 \%$ of PIW are present within the realm of DSOW (average of $11 \pm 6 \% ; n=91$; Fig. 4f), supporting the existence of entrainment of East Greenland shelf waters into DSOW (e.g. Pickart et al., 2005; Falina et al., 2012; Jochumsen et al., 2015). PIW is also found on the continental shelves and slopes of Greenland and Canada, with the greatest contribution found on the Canadian shelf. The appearance of PIW on the Canadian shelf is in agreement with the exchange of Arctic waters occurring via the Canadian Arctic Archipelago, Baffin Bay and Davis Strait (Curry et al., 2014), which then join the Labrador Current and intersect the GEOTRACES-GA01 section (Fig. 1).

The dominant deep water in the West European Basin is $\mathrm{NEADW}_{\mathrm{L}}$ (Fig. 4h), which extends from $2000 \mathrm{dbar}$ to the bottom. The location of $\mathrm{NEADW}_{\mathrm{L}}$ coincides with the higher concentrations of silicic acid measured in section ( $>20 \mu \mathrm{mol} \mathrm{kg}{ }^{-1}$; Fig. 2d), supporting the influence of Antarctic Bottom Water in $\mathrm{NEADW}_{\mathrm{L}}$ (van Aken and Becker, 1996).

\section{Water mass volume transports for 2014}

Water mass volume transports across the 2014 OVIDE line (Portugal to Greenland section) result from combining the water mass fractions from the eOMP analysis ( $X_{i}$ values) with the absolute geostrophic velocity field. The absolute geostrophic field orthogonal to the 2014 OVIDE line was estimated by a box inverse model, using the hydrologic profiles measured at each station, and constrained by ADCP velocity measurements and by a net volume transport of $1 \pm 3 \mathrm{~Sv}$ northwards to ensure mass conservation (Lherminier et al., 2007, 2010; Zunino et al., 2017).

To allow the combination of the $X_{i}$ values with the absolute geostrophic velocity field, the $X_{i}$ values were linearly interpolated in density coordinates to match the grid of the absolute geostrophic velocity. Then the $X_{i}$ values were multiplied by the absolute geostrophic velocity field, to estimate the water mass volume transports orthogonal to the section. The resulting water mass volume transports were then integrated along the section to obtain the net water mass volume transports (represented in sverdrups; $1 \mathrm{~Sv}=10^{6} \mathrm{~m}^{3} \mathrm{~s}^{-1}$ ) (Fig. 5). Northward (southward) water mass volume transports are positive (negative). Errors were computed by propagating both the uncertainty of the $X_{i}$ values (listed in Table 1) and the uncertainty of the velocity field. 


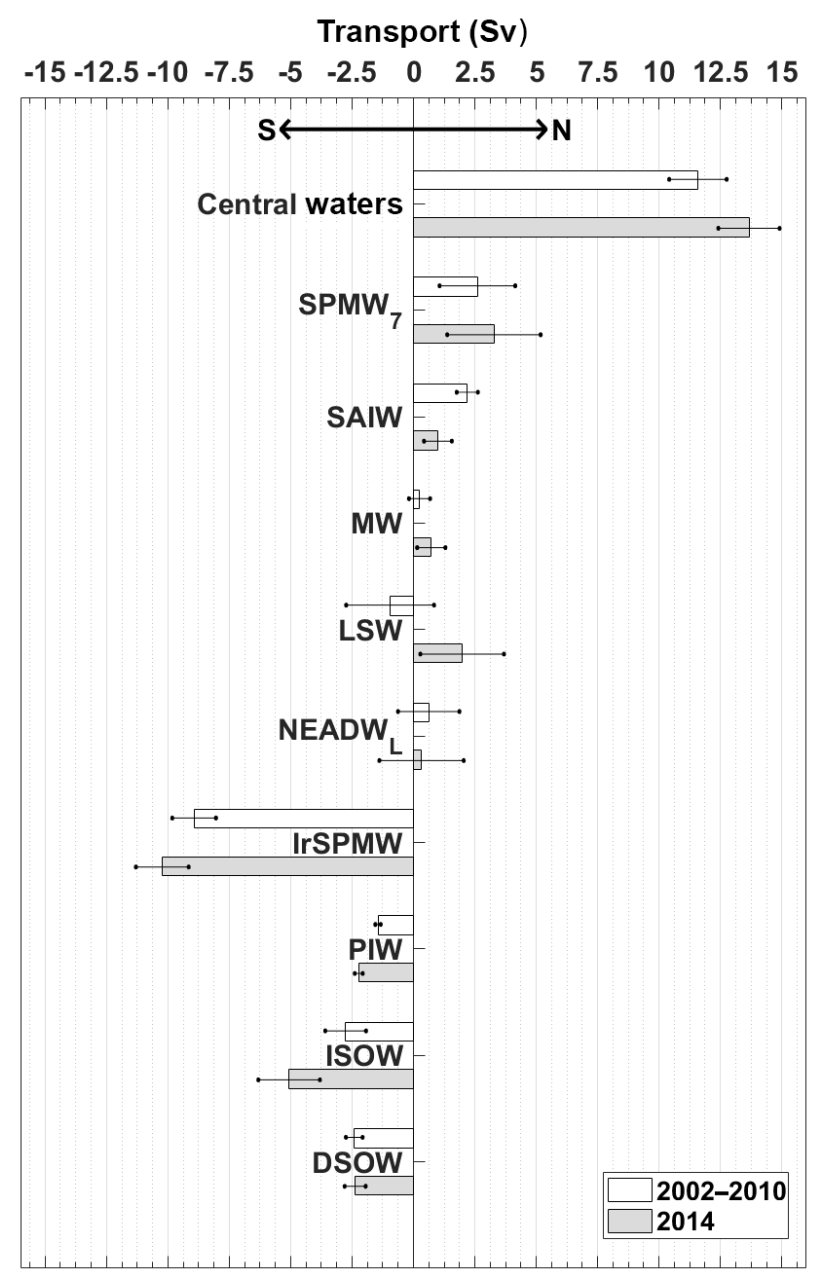

Figure 5. Net water mass volume transports (in $\mathrm{Sv}$; $1 \mathrm{~Sv}=10^{6} \mathrm{~m}^{3} \mathrm{~s}^{-1}$ ) perpendicular to the OVIDE line for the 2002-2010 period (white bars; from García-Ibáñez et al., 2015) and for 2014 (grey bars). Transports are positive (negative) northwards (southwards). Central Waters refers to the sum of $\mathrm{ENACW}_{16}$, ENACW $_{12}$ and $\mathrm{SPMW}_{8}$; and SAIW to the sum of $\mathrm{SAIW}_{6}$ and $\mathrm{SAIW}_{4}$ (consult Table 1 for water mass acronyms). Error bars represent the error in the net water mass volume transport for 2014 and the standard deviation from the average net water mass volume transport for 2002-2010.

We describe the water mass volume transports based on their contribution to the upper and lower limbs of the AMOC. Across the OVIDE line, the upper and lower limbs of the AMOC are separated by the isopycnal $\sigma_{1}=32.15 \mathrm{~kg} \mathrm{~m}^{-3}$ (Mercier et al., 2015; Zunino et al., 2017), where $\sigma_{1}$ refers to potential density referenced to $1000 \mathrm{dbar}$. The upper limb of the AMOC for the 2014 OVIDE line is represented by the Central Waters $\left(\mathrm{ENACW}_{16}, \mathrm{ENACW}_{12}\right.$ and $\mathrm{SPMW}_{8}$; $13.7 \pm 1.2 \mathrm{~Sv}), \mathrm{SPMW}_{7}(3.3 \pm 1.9 \mathrm{~Sv})$ and SAIW $\left(\mathrm{SAIW}_{6}\right.$ and $\mathrm{SAIW}_{4} ; 1.0 \pm 0.6 \mathrm{~Sv}$ ) (Fig. 5). We also included the net northward transport of MW $(0.7 \pm 0.6 \mathrm{~Sv})$ to the AMOC upper limb, since it contributes to the formation of interme- diate waters in the SPNA (Reid, 1979, 1994). These flows altogether result in an AMOC upper limb of $18.7 \pm 2.4 \mathrm{~Sv}$ for OVIDE 2014, which is in good agreement with the $18.7 \pm 3.0 \mathrm{~Sv}$ for the intensity of the AMOC reported for OVIDE 2014 by Zunino et al. (2017). The AMOC intensity is defined as the maximum of the surface-to-bottom integrated stream function computed in density coordinates (Zunino et al., 2017). The contributors of the upper limb of the AMOC agree with the subpolar (SAIW and $\mathrm{SPMW}_{7}$ ) and subtropical (Central Waters) components of the AMOC at the OVIDE sections described by Desbruyères et al. (2013).

The observed net volume transport for Central Waters $\left(\mathrm{ENACW}_{16}, \mathrm{ENACW}_{12}\right.$ and $\left.\mathrm{SPMW}_{8}\right)$ across the 2014 OVIDE line is in agreement with the average value of $11.6 \pm 1.4$ Sv for 2002-2010 (García-Ibáñez et al., 2015) but lower than the $19.6 \pm 1.7 \mathrm{~Sv}$ for 1997 reported as the net transport of the NAC by Lherminier et al. (2007). The higher volume transport of Central Waters in 1997 is linked to the higher AMOC intensity reported for that year $(23.3 \pm 1.2 \mathrm{~Sv}$; Lherminier et al. 2007) with respect to the AMOC intensity reported for 2014 (18.7 $\pm 3.0 \mathrm{~Sv}$; Zunino et al., 2017).

The AMOC lower limb at the 2014 OVIDE line is, then, constituted by the remainder water masses, i.e. IrSPMW $(-10.2 \pm 1.1 \mathrm{~Sv}), \quad$ LSW $(2.0 \pm 1.7 \mathrm{~Sv})$, ISOW $\quad(-5.1 \pm 1.3 \mathrm{~Sv}), \quad$ DSOW $\quad(-2.4 \pm 0.4 \mathrm{~Sv}), \quad$ PIW $(-2.2 \pm 0.2 \mathrm{~Sv})$ and $\mathrm{NEADW}_{\mathrm{L}}(0.3 \pm 1.7 \mathrm{~Sv})$ (Fig. 5), resulting in a southward transport of $-17.6 \pm 3.0 \mathrm{~Sv}$. The net volume transport of LSW for OVIDE 2014 is in agreement with the $2 \pm 1 \mathrm{~Sv}$ reported for OVIDE 2002 by Lherminier et al. (2007). The net southward transport of ISOW for OVIDE 2014 is significantly higher than previous estimates of about -3 Sv (e.g. Saunders, 1996; van Aken and Becker, 1996; Lherminier et al., 2007; Sarafanov et al., 2012). However, it is in agreement with the $-5.8 \pm 0.9 \mathrm{~Sv}$ observed at the OSNAP array $\left(58-59^{\circ} \mathrm{N}\right)$ between July 2014 and July 2016 (Johns et al., 2017). The transport of PIW was split into that associated with its distribution in the upper $2000 \mathrm{dbar}$, and that associated with its distribution deeper than $2000 \mathrm{dbar}$ (samples assigned to mixing group 3; Fig. 3c), which was added to DSOW to agree with the cascading events occurring along DSOW pathway (e.g. Pickart et al., 2005; Falina et al., 2012; Jochumsen et al., 2015). The net volume transport of the shallow core of PIW across OVIDE 2014 is in agreement with previous estimates of around $-2 \mathrm{~Sv}$ entering from the Arctic Ocean (barely $-2 \mathrm{~Sv}$ reported by Pickart et al., 2005, and an average transport of $-2.4 \pm 0.3 \mathrm{~Sv}$ reported by Falina et al., 2012, for 2002-2004). The net volume transport of DSOW across OVIDE $2014(-2.2 \pm 0.4 \mathrm{~Sv}$; Fig. 5) is in good agreement with the estimates of Ross (1984) (from -2 to $-3 \mathrm{~Sv})$, Eden and Willebrand (2001) ( $-2.5 \mathrm{~Sv})$, Lherminier et al. (2010) ( $-2 \mathrm{~Sv}$ for the OVIDE sections of 2002 and 2004), and García-Ibáñez et al. (2015) $(-2.4 \pm 0.3 \mathrm{~Sv}$ for OVIDE 2002-2010). However, our estimate is slightly lower than the $-3 \mathrm{~Sv}$ widely recognized as the long-term average transport of DSOW (e.g. Dickson and Brown, 1994; 


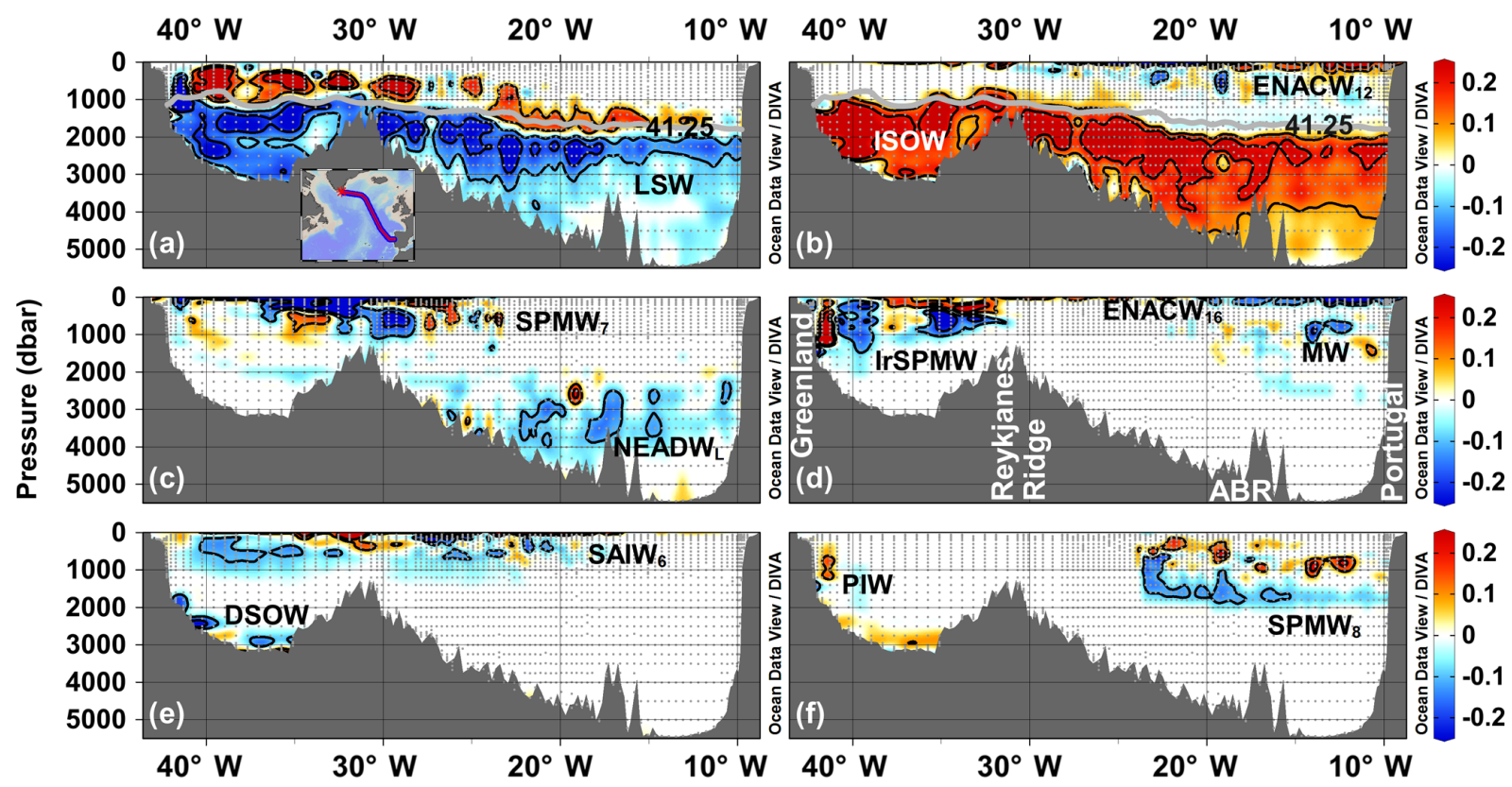

Figure 6. Water mass differences between the OVIDE line (inset in subplot a) in 2014 and the average of 2002-2010, from Portugal (right) to Greenland (left). Positive (negative) anomalies in the proportion of a water mass imply a gain (loss) in 2014 compared to 2002-2010. The grey line in subplots (a) and (b) represents the isopycnal $\sigma_{3}=41.25 \mathrm{~g} \mathrm{~m}^{-3}$ discussed in the text. The changes in SAIW 4 are not shown due to its low representation along the section. Sample locations appear as grey dots. ABR refers to Azores-Biscay Rise. Consult Table 1 for water mass acronyms.

Macrander et al., 2005; Jochumsen et al., 2017). Finally, the $\mathrm{NEADW}_{\mathrm{L}}$ net volume transport across OVIDE 2014 is compatible with previous estimates of about $1 \mathrm{~Sv}$ (e.g. van Aken and Becker, 1996).

\section{Differences in the water mass distribution and volume transport between OVIDE 2014 and the average OVIDE 2002-2010}

In this section, we describe and discuss the observed changes in the water mass distribution along the OVIDE line (Portugal to Greenland) between 2002-2010 and 2014 (Fig. 6). We also describe and discuss how the changes in water mass distributions are reflected in the water mass volume transport across the OVIDE line (Fig. 5).

To obtain the differences in water mass proportions between 2002-2010 and 2014, we interpolated the water mass distributions of 2014 from this study and those of 2002-2010 from García-Ibáñez et al. (2015) to a common grid using a Delaunay triangulation. The selected grid was the sampling locations from the OVIDE 2010 cruise. Positive (negative) anomalies in the proportion of a water mass imply a gain (loss) in 2014 compared to 2002-2010.

The high mesoscale variability of the study area, with changes in the location of fronts and eddies (Zunino et al., 2017), leads to changes in the water mass proportions between 2002-2010 and 2014 in alternative patterns of in- creases and decreases (Fig. 6). However, some water masses show persistent and regionally localized changes linked to changes in the hydrographic properties of the OVIDE section, which are further discussed.

Since our OMP analysis considers time-invariant properties characterizing the SWTs, the inter-annual variability in the water mass properties at formation is solved by the OMP analysis through water mass redistributions. Therefore, the observed changes in the thermohaline properties between 2002-2010 and 2014 are reflected by the redistribution of water masses. However, note that the properties describing LSW and ISOW were adjusted to better represent their warming and salinization observed since the 2000s (see Sect. 2.3) (e.g. Hansen et al., 2016; Yashayaev and Loder, 2017). For alternative comparative purposes, the water mass distribution using the same SWT properties as in GarcíaIbáñez et al. (2015) is given in Fig. S2 in the Supplement.

The water masses that have experienced the greatest change in their proportions along the OVIDE line between the 2002-2010 mean and 2014 are LSW and ISOW. The changes in LSW follow two general patterns separated by the isopycnal $\sigma_{3}=41.25 \mathrm{~kg} \mathrm{~m}^{-3}$ : an increase above it and a decrease below it with respect to 2002-2010 (Fig. 6a). Comparing our Fig. 6 with Fig. 7 in Zunino et al. (2017), the isopycnal of $\sigma_{3}=41.25 \mathrm{~kg} \mathrm{~m}^{-3}$ represents the upper bound of the warming, salinification and deoxygenation in 2014 with respect to 2002-2012. The positive LSW anomalies coincide with negative anomalies of the SPMWs and 
SAIW $_{6}$. In the West European Basin, LSW replaced SPMW 8 (Fig. 6f); around and over the Reykjanes Ridge, LSW replaced $\mathrm{SPMW}_{7}$ (Fig. 6c); and in the Irminger Sea, LSW replaced IrSPMW and SAIW $_{6}$ (Fig. 6d, e), with the exception of the EGIC where IrSPMW replaced LSW. The increase in the relatively cold LSW at the expense of the relatively warm SPMWs is a response to the cold and fresh anomalies in surface and intermediate waters in the 2014 with respect to 2002-2012 (Zunino et al., 2017), which is in agreement with the long-term cooling of the North Atlantic Subpolar Gyre that started in the mid-2000s (e.g. Robson et al., 2016; Piecuch et al., 2017). The long-term cooling of the subpolar gyre is also observed by a redistribution in between the different end-members of the Central Waters and SPMW, where the colder end-members (ENACW 12 and IrSPMW; Fig. 6b, d) replaced the warmer end-members $\left(\right.$ ENACW $_{16}$ and $\mathrm{SPMW}_{7}$; Fig. 6d, c) in 2014 with respect to 2002-2010. The replacement of LSW by IrSPMW and PIW (Fig. 6f) in the EGIC could be linked to the formation of LSW-like water in the Irminger Sea (de Jong and de Steur, 2016), in which properties are in between our end-members for IrSPMW and PIW. The redistribution between LSW and IrSPMW in the EGIC could have also been caused by the narrowing of the Irminger Gyre in 2014 with respect to 2002-2012 (Zunino et al., 2017).

Below $\sigma_{3}=41.25 \mathrm{~kg} \mathrm{~m}^{-3}$, the decrease in the contribution of LSW in 2014 with respect to 2002-2010 is balanced by an increase in ISOW (Fig. 6b). This water mass redistribution responds both to the salinization of LSW (e.g. Yashayaev and Loder, 2017), and to the lower density of LSW formed in recent years that occupies shallower positions in the water column. García-Ibáñez et al. (2015) also reported how the progressive salinization of LSW since the late 1990s resulted in a progressive decrease in LSW and increase in ISOW. East of $22^{\circ} \mathrm{W}$, the increase in ISOW compensates for the decrease in $\mathrm{NEADW}_{\mathrm{L}}$, which is linked to a decrease in silicic acid in the range of $20-35 \mu \mathrm{mol} \mathrm{kg}^{-1}$ (i.e. in the mixing zone between ISOW and NEADW) in 2014 compared to 2002-2010 (Fig. S3 in the Supplement). The uniform increase in ISOW is consistent with the increase in volume transport of ISOW observed in the OSNAP array along 58-59 $\mathrm{N}$ (Johns et al., 2017; Zou et al., 2017).

The proportion of DSOW generally decreases with respect to 2002-2010 (Fig. 6e), being partially compensated for by an increase in PIW (Fig. 6f). The contrasting changes in DSOW corroborates the variability in the composition of DSOW and in the entrainment events (e.g. Macrander et al., 2005; Tanhua et al., 2008; Falina et al., 2012; van Aken and de Jong, 2012).

The changes in the remaining water masses are attributable to mesoscale activity. The changes observed in MW (Fig. 6d) might be caused by meddy activity (Arhan and King, 1995; Mazé et al., 1997) that, in 2014, mixed MW with SPMW $_{8}$ (Fig. 6f). The interchange between $\mathrm{SAIW}_{6}$ (Fig. 6e) and $\mathrm{SPMW}_{7}$ (Fig. 6c) is explained by the relatively warm and salty anticyclonic eddy found at the northern limit of the NAC (Zunino et al., 2017; their Figs. 5 and 7).

The discussed changes in water mass distributions between the 2002-2010 mean and 2014 led to changes in the water mass volume transport across the OVIDE line (Fig. 5). Most of the changes in the net water mass volume transports between 2014 and the 2002-2010 mean are within the errors and, therefore, are not significant, with the exception of SAIW, PIW and ISOW, which are further discussed.

The observed net volume transport of $1.0 \pm 0.6 \mathrm{~Sv}$ for SAIW (SAIW 6 and SAIW $_{4}$ ) across the OVIDE 2014 line is lower than the average value of $2.2 \pm 0.4 \mathrm{~Sv}$ for 2002 2010 (García-Ibáñez et al., 2015), and the 2.9 Sv reported by Álvarez et al. (2004) for 1997. The lower SAIW transport in 2014 compared to 1997 and 2002-2010 is related to the generally lower proportions of SAIW in 2014, associated with the cold and fresh anomalies in surface and intermediate waters in 2014 with respect to 2002-2012 (Zunino et al., 2017). The net volume transport of the shallow core of PIW across OVIDE $2014(-2.2 \pm 0.2 \mathrm{~Sv})$ agrees with previous estimates of around $-2 \mathrm{~Sv}$ entering from the Arctic Ocean (barely $-2 \mathrm{~Sv}$ reported by Pickart et al. (2005), and an average transport of $-2.4 \pm 0.3 \mathrm{~Sv}$ reported by Falina et al. (2012) for 2002-2004). However, the net volume transport of PIW in 2014 is significantly higher than the average value of $-1.4 \pm 0.1 \mathrm{~Sv}$ for OVIDE 2002-2010 (GarcíaIbáñez et al., 2015). The increase in the contribution of PIW to the EGIC (Fig. 6f) explains the observed increase in the transport of PIW in 2014.

The net southward transport of ISOW for OVIDE 2014 $(-5.1 \pm 1.3 \mathrm{~Sv})$ is significantly higher than previous estimates of about $-3 \mathrm{~Sv}$ (e.g. Saunders, 1996; van Aken and Becker, 1996; Lherminier et al., 2007; Sarafanov et al., 2012). The ISOW transport is also significantly higher than the average value of $-2.8 \pm 0.8 \mathrm{~Sv}$ for OVIDE 2002-2010 (García-Ibáñez et al., 2015). However, the net volume transport of ISOW found in 2014 is in agreement with the $-5.8 \pm 0.9 \mathrm{~Sv}$ observed at the OSNAP array $\left(58-59^{\circ} \mathrm{N}\right)$ between July 2014 and July 2016 (Johns et al., 2017).

The assessment of the relative contribution of each water mass to the AMOC across the OVIDE line allows the identification of the water masses involved in the slight increase in the AMOC intensity from the average value of $16.2 \pm 2.4 \mathrm{~Sv}$ for OVIDE 2002-2010 to $18.7 \pm 3.0 \mathrm{~Sv}$ for OVIDE 2014 (Zunino et al., 2017). An increase in the AMOC intensity implies an increase in the net northward and southward transports of its upper and lower limbs, respectively. The increase in the AMOC intensity is related to the increase in the northward transport of the Central Waters in its upper limb, and to the increase in the southward flow of IrSPMW and ISOW in its lower limb. 


\section{Conclusions}

We described and discussed the distribution of water masses along the GEOVIDE cruise (GEOTRACES-GA01 section), crossing the subpolar North Atlantic Ocean and the Labrador Sea in summer 2014. We also provided the relative contribution from each water mass to the transports across the OVIDE line (Portugal to Greenland) of the GEOTRACES-GA01 section by combining the eOMP results with the velocity field. The water mass structure along the GEOTRACES-GA01 section, obtained through an eOMP analysis, is consistent with generally accepted knowledge of the subpolar North Atlantic circulation, with the exception of higher ISOW presence than the mean values reported in the literature. Our estimates of water mass transports are in good agreement with previous studies and match the main features of the northern North Atlantic Circulation, with the exception of higherthan-expected transport of ISOW linked to the high proportion of this water mass along the section. However, our net water mass volume transport of ISOW in 2014 is in agreement with the observed increase in the ISOW transport at $58-59^{\circ} \mathrm{N}$ since 2014.

We also assessed the change in the water mass distribution and transport of the 2014 OVIDE line, by comparing them with the average OVIDE 2002-2010. At the upper and intermediate water levels, the colder end-members of Central Waters and SPMW as well as LSW replaced warmer water masses in 2014 with respect to 2002-2010, in agreement with the observed cooling of the North Atlantic Subpolar Gyre that started in the mid-2000s. Below 2000 dbar, ISOW presents greater proportions in 2014 than in 2002-2010, with the increase being consistent with other estimates of ISOW transports along $58-59^{\circ} \mathrm{N}$. We also observed an increase in IrSPMW and PIW within the EGIC in 2014 with respect to 2002-2010, an admixture similar to LSW, which supports the recent deep convection events in the Irminger Sea. This comparison of the water mass distribution for OVIDE 2014 and 2002-2010 highlights the utility of the eOMP analysis for identifying temporal variations in water mass distributions linked to circulation changes and water mass transformation.

The quantification of the volume transport for each water mass into the two limbs of the AMOC allowed us to identify the water masses implicated in the strengthening of the AMOC at the OVIDE line in 2014 in relation to the 20022010 average. The increase in the intensity of the AMOC upper limb is related to the increase in the northward transport of the Central Waters, which is partially compensated for by the increase in the southward flow of IrSPMW and ISOW in the AMOC lower limb.

Data availability. The 2014 GEOVIDE (GEOTRACES-GA01 and GO-SHIP A25) data from the classical rosette is available at SEANOE: http://doi.org/10.17882/54653 (Perez et al., 2018). The
Greenland-Portugal ADCP data are available at SEANOE: http: //doi.org/10.17882/52153 (Lhermier and Sharthou, 2017).

\section{The Supplement related to this article is available online at https://doi.org/10.5194/bg-15-2075-2018-supplement.}

Author contributions. All authors contributed extensively to the work presented in this paper. MIGI, FFP and PL designed the research. MIGI, FFP, PL, PZ, HM and PT analysed the physical and chemical data. MIGI and FFP developed the code for processing the data. MIGI wrote the paper and prepared all figures, with contributions from all co-authors.

Competing interests. The authors declare that they have no conflict of interest.

Special issue statement. This article is part of the special issue "GEOVIDE, an international GEOTRACES study along the OVIDE section in the North Atlantic and in the Labrador Sea (GA01)". It is not associated with a conference.

Acknowledgements. We are grateful to the captains, staff and researchers who contributed to the acquisition and processing of hydrographic data. We are especially grateful to Morgane Gallinari, Emilie Grosstefan and Manon Le Goff, who contributed to the analysis of nutrients, and to the technical team: Pierre Branellec, Floriane Desprez de Gésincourt, Michel Hamon, Catherine Kermabon, Philippe Le Bot, Stéphane Leizour, Olivier Ménage, Fabien Pérault and Emmanuel de Saint-Léger. For this work Maribel I. García-Ibáñez and Fiz F. Pérez were supported by the Spanish Ministry of Economy and Competitiveness through the BOCATS (CTM2013-41048-P) project, co-funded by the Fondo Europeo de Desarrollo Regional 2014-2020 (FEDER). Maribel I. García-Ibáñez was also supported by the Centre for Climate Dynamics at the Bjerknes Centre. Pascale Lherminier was supported by IFREMER. Patricia Zunino was supported by CNRS and IFREMER, within the framework of the projects AtlantOS (H2020-633211) and GEOVIDE (ANR-13-BS06-0014-02). Herlé Mercier was supported by CNRS and the AtlantOS H2020 project under grant number 633211. Paul Tréguer was supported by the LABEX-Mer (French Government "Investissement d'Avenir" programme, ANR-10-LABX-19-01).

Edited by: Gilles Reverdin

Reviewed by: three anonymous referees

\section{References}

Álvarez, M., Pérez, F. F., Bryden, H., and Ríos, A. F.: Physical and biogeochemical transports structure in the North 
Atlantic subpolar gyre, J. Geophys. Res., 109, C03027, https://doi.org/10.1029/2003JC002015, 2004.

Álvarez, M., Pérez, F. F., Shoosmith, D. R., and Bryden, H. L.: Unaccounted role of Mediterranean Water in the drawdown of anthropogenic carbon, J. Geophys. Res.-Oceans, 110, C09S03, https://doi.org/10.1029/2004JC002633, 2005.

Ambar, I. and Howe, M. R.: Observations of the Mediterranean outflow-I: mixing in the Mediterranean outflow, Deep-Sea Res., 26, 535-554, https://doi.org/10.1016/0198-0149(79)90095-5, 1979.

Anderson, L. A. and Sarmiento, J. L.: Redfield ratios of remineralization determined by nutrient data analysis, Global Biogeochem. Cy., 8, 65-80, https://doi.org/10.1029/93GB03318, 1994.

Arhan, M.: The North Atlantic Current and subarctic intermediate water, J. Mar. Res., 48, 109-144, https://doi.org/10.1357/002224090784984605, 1990.

Arhan, M. and King, B.: Lateral mixing of the Mediterranean Water in the eastern North Atlantic, J. Mar. Res., 53, 865-895, https://doi.org/10.1357/0022240953212990, 1995.

Baringer, M. O. and Price, J. F.: Mixing and spreading of the Mediterranean outflow, J. Phys. Oceanogr., 27, 1654-1677, https://doi.org/10.1175/15200485(1997)027<1654:MASOTM>2.0.CO;2, 1997.

Bersch, M., Yashayaev, I., and Koltermann, K. P.: Recent changes of the thermohaline circulation in the subpolar North Atlantic, Ocean Dynam., 57, 223-235, https://doi.org/10.1007/s10236007-0104-7, 2007.

Brambilla, E. and Talley, L. D.: Subpolar Mode Water in the northeastern Atlantic: 1. Averaged properties and mean circulation, J. Geophys. Res., 113, C04025, https://doi.org/10.1029/2006JC004062, 2008.

Bubnov, V. A.: Intermediate subarctic waters in the northern part of the Atlantic Ocean, Okeanologia, 19, 136-153 (English translation, N00 Trans 545, U.S. Nav. Oceanogr. Off., Washington, D.C., 1973), 1968.

Carracedo, L. I., Pardo, P. C., Villacieros-Robineau, N., De la Granda, F., Gilcoto, M., and Pérez, F. F.: Temporal changes in the water mass distribution and transports along the $20^{\circ} \mathrm{W}$ CAIBOX section (NE Atlantic), Cienc. Mar., 38, 263-286, https://doi.org/10.7773/cm.v38i1B.1793, 2012.

Carracedo, L. I., Gilcoto, M., Mercier, H., and Pérez, F. F.: Seasonal dynamics in the Azores-Gibraltar Strait region: a climatologically-based study, Prog. Oceanogr., 122, 116-130, https://doi.org/10.1016/j.pocean.2013.12.005, 2014.

Castro, C. G., Pérez, F. F., Holley, S. E., and Ríos, A. F.: Chemical characterisation and modelling of water masses in the Northeast Atlantic, Prog. Oceanogr., 41, 249-279, https://doi.org/10.1016/S0079-6611(98)00021-4, 1998.

Curry, B., Lee, C. M., Petrie, B., Moritz, R. E., and Kwok, R.: Multiyear Volume, Liquid Freshwater, and Sea Ice Transports through Davis Strait, 2004-10, J. Phys. Oceanogr., 44, 12441266, https://doi.org/10.1175/JPO-D-13-0177.1, 2014.

Daniault, N., Lherminier, P., and Mercier, H.: Circulation and transport at the southeast tip of Greenland, J. Phys. Oceanogr., 41, 437-457, https://doi.org/10.1175/2010JPO4428.1, 2011.

Daniault, N., Mercier, H., Lherminier, P., Sarafanov, A., Falina, A., Zunino, P., Pérez, F. F., Ríos, A. F., Ferron, B., Huck, T., Thierry, V., and Gladyshev, S.: The northern North Atlantic Ocean mean circulation in the early 21 st century, Prog. Oceanogr., 146, 142 158, https://doi.org/10.1016/j.pocean.2016.06.007, 2016.

de Boisséson, E., Thierry, V., Mercier, H., Caniaux, G., and Desbruyères, D.: Origin, formation and variability of the Subpolar Mode Water located over the Reykjanes Ridge, J. Geophys. Res., 117, C12005, https://doi.org/10.1029/2011JC007519, 2012.

de Jong, M. F. and de Steur, L.: Strong winter cooling over the Irminger Sea in winter 2014-2015, exceptional deep convection, and the emergence of anomalously low SST, Geophys. Res. Lett., 43, 7106-7113, https://doi.org/10.1002/2016GL069596, 2016.

Desbruyères, D., Thierry, V., and Mercier, H.: Simulated decadal variability of the meridional overturning circulation across the A25-Ovide section, J. Geophys. Res.-Oceans, 118, 462-475, https://doi.org/10.1029/2012JC008342, 2013.

Dickson, R. R. and Brown, J.: The production of North Atlantic Deep Water: sources, rates, and pathways, J. Geophys. Res., 99, 12319-12341, https://doi.org/10.1029/94JC00530, 1994.

Dickson, B., Yashayaev, I., Meincke, J., Turrell, B., Dye, S., and Holfort, J.: Rapid freshening of the deep North Atlantic Ocean over the past four decades, Nature, 416, 832-837, https://doi.org/10.1038/416832a, 2002.

Eden, C. and Willebrand, J.: Mechanism of interannual to decadal variability of the North Atlantic Circulation, J. Climate, 14, 2266-2280, https://doi.org/10.1175/15200442(2001)014<2266:MOITDV>2.0.CO;2, 2001.

Falina, A., Sarafanov, A., Mercier, H., Lherminier, P., Sokov, A., and Daniault, N.: On the cascading of dense shelf waters in the Irminger Sea, J. Phys. Oceanogr., 42, 2254-2267, https://doi.org/10.1175/JPO-D-12-012.1, 2012.

Ferron, B., Kokoszka, F., Mercier, H., and Lherminier, P.: Dissipation rate estimates from microstructure and finescale internal wave observations along the A25 Greenland-Portugal OVIDE line, J. Atmos. Ocean. Techn., 31, 2530-2543, https://doi.org/10.1175/JTECH-D-14-00036.1, 2014.

Fleischmann, U., Hildebrandt, H., Putzka, A., and Bayer, R.: Transport of newly ventilated deep water from the Iceland Basin to the West European Basin, Deep-Sea Res., 48B, 1793-1819, https://doi.org/10.1016/S0967-0637(00)00107-2, 2001.

Fogelqvist, E., Blindheim, J., Tanhua, T., Østerhus, S., Buch, E., and Rey, F.: Greenland-Scotland overflow studied by hydrochemical multivariate analysis, Deep-Sea Res. Pt I, 50, 73-102, https://doi.org/10.1016/S0967-0637(02)00131-0, 2003.

Fröb, F., Olsen, A., Våge, K., Moore, G. W. K., Yashayaev, I., Jeansson, E., and Rajasakaren, B.: Irminger Sea deep convection injects oxygen and anthropogenic carbon to the ocean interior, Nat. Commun., 7, 13244, https://doi.org/10.1038/ncomms13244, 2016.

García-Ibáñez, M. I., Pardo, P. C., Carracedo, L. I., Mercier, H., Lherminier, P., Ríos, A. F., and Pérez F. F.: Structure, transports and transformations of the water masses in the Atlantic Subpolar Gyre, Prog. Oceanogr., 135, 18-36, https://doi.org/10.1016/j.pocean.2015.03.009, 2015.

Hansen, B., Húsgarð Larsen, K. M., Hátún, H., and Østerhus, S.: A stable Faroe Bank Channel overflow 1995-2015, Ocean Sci., 12, 1205-1220, https://doi.org/10.5194/os-12-1205-2016, 2016.

Harvey, J.: Theta-S relationships and water masses in the eastern North Atlantic, Deep-Sea Res., 29, 1021-1033, https://doi.org/10.1016/0198-0149(82)90025-5, 1982. 
Harvey, J. and Arhan M.: The water masses of the central North Atlantic in 1983-84, J. Phys. Oceanogr., $18, \quad 1855-1875$, https://doi.org/10.1175/15200485(1988)018<1855:TWMOTC >2.0.CO;2, 1988.

Iselin, C. O.: A Study of the Circulation of the Western North Atlantic, Pap. Phys. Oceanogr. Meteorol., Massachusetts Inst. Tech. and Woods Hole Oceanographic Inst, 101 pp., https://doi.org/10.1575/1912/1087, 1936.

Jochumsen, K., Köllner, M., Quadfasel, D., Dye, S., Rudels, B., and Valdimarsson, H.: On the origin and propagation of Denmark Strait overflow water anomalies in the Irminger Basin, J. Geophys. Res.-Oceans, 120, 1841-1855, https://doi.org/10.1002/2014JC010397, 2015.

Jochumsen, K., Moritz, M., Nunes, N., Quadfasel, D., Larsen, K. M. H., Hansen, B., Valdimarsson, H., and Jonsson, S.: Revised transport estimates of the Denmark Strait overflow, J. Geophys. Res.-Oceans, 122, 3434-3450, https://doi.org/10.1002/2017JC012803, 2017.

Johns, W., Houk, A., Koman, G., Zou, S., and Lozier, S.: Transport of Iceland-Scotland Overflow waters in the Deep Western Boundary Current along the Reykjanes Ridge, Geophysical Research Abstracts, 19, EGU2017-9415, 2017.

Karstensen, J. and Tomczak M.: Age determination of mixed water masses using CFC and oxygen data, J. Geophys. Res., 103, 18599-18609, https://doi.org/10.1029/98JC00889, 1998.

Kieke, D. and Yashayaev, I.: Studies of Labrador Sea Water formation and variability in the subpolar North Atlantic in the light of international partnership and collaboration, Prog. Oceanogr., 132, 220-232, https://doi.org/10.1016/j.pocean.2014.12.010, 2015.

Krauss, W.: Currents and mixing in the Irminger Sea and in the Iceland Basin, J. Geophys. Res., 100, 10851-10871, https://doi.org/10.1029/95JC00423, 1995.

Kuhlbrodt, T., Griesel, A., Montoya, M., Levermann, A., Hofmann, M., and Rahmstorf, S.: On the driving processes of the Atlantic meridional overturning circulation, Rev. Geophys., 45, RG2001, https://doi.org/10.1029/2004RG000166, 2007.

Lauderdale, J. M., Bacon, S., Naveira Garabato, A. C., and Holliday, N. P.: Intensified turbulent mixing in the boundary current system of southern Greenland, Geophys. Res. Lett., 35, L04611, https://doi.org/10.1029/2007GL032785, 2008.

LeBel, D. A., Smethie Jr., W. M., Rhein, M., Kieke, D., Fine, R. A., Bullister, J. L., Min D., Roether, W., Weiss, R. F., Andrié, C., Smythe-Wright, and D., Jones P. E.: The formation rate of North Atlantic Deep Water and eighteen Degree water calculated from CFC-11 inventories observed during WOCE, Deep-Sea Res. Pt I, 55, 891-910, https://doi.org/10.1016/j.dsr.2008.03.009, 2008.

Leffanue, H. and Tomczak, M.: Using OMP analysis to observe temporal variability in water mass distribution, J. Marine. Syst., 48, 3-14, https://doi.org/10.1016/j.jmarsys.2003.07.004, 2004.

Lherminier, P., Mercier, H., Gourcuff, C., Alvarez, M., Bacon, S., and Kermabon, C.: Transports across the 2002 GreenlandPortugal Ovide section and comparison with 1997, J. Geophys. Res., 112, C07003, https://doi.org/10.1029/2006JC003716, 2007.

Lherminier, P., Mercier, H., Huck, T., Gourcuff, C., Perez, F. F., Morin, P., Sarafanov, A., and Falina, A.: The Atlantic Meridional Overturning Circulation and the subpolar gyre observed at the
A25-OVIDE section in June 2002 and 2004, Deep-Sea Res. Pt I, 57, 1374-1391, https://doi.org/10.1016/j.dsr.2010.07.009, 2010.

Lherminier, P. and Sarthou, G.: The 2014 Greenland-Portugal GEOVIDE CTDO2 hydrographic and SADCP data (GO-SHIP A25 and GEOTRACES GA01), SEANOE, available at: http://doi.org/ 10.17882/52153, last access: 22 November 2017.

Macrander, A., Send, U., Valdimarsson, H., Jónsson, S., and Käse, R. H.: Interannual changes in the overflow from the Nordic Seas into the Atlantic Ocean through Denmark Strait, Geophys. Res. Lett., 32, L06606, https://doi.org/10.1029/2004GL021463, 2005.

Malmberg, S. A.: Intermediate polar water in the Denmark strait overflow August 1971, International Council for the Exploration of the Sea Conference Meeting, 6, 44-60, 1972.

Mantyla, A. W.: The treatment of inconsistencies in Atlantic deep water salinity data, Deep-Sea Res. Pt I, 41, 1387-1405, https://doi.org/10.1016/0967-0637(94)90104-X, 1994.

Mazé, J. P., Arhan, M., and Mercier, H.: Volume budget of the eastern boundary layer off the Iberian Peninsula, Deep-Sea Res. Pt I, 44, 1543-1574, https://doi.org/10.1016/S0967-0637(97)000381,1997

McCartney, M. S. and Talley, L. D.: The subpolar mode water of the North Atlantic Ocean, J. Phys. Oceanogr., 12, 1169-1188, https://doi.org/10.1175/15200485(1982)012<1169:TSMWOT>2.0.CO;2, 1982.

Mercier, H., Lherminier, P., Sarafanov, A., Gaillard, F., Daniault, N., Desbruyères, D., Falina, A., Ferron, B., Gourcuff, C., Huck, T., and Thierry, V.: Variability of the meridional overturning circulation at the Greenland-Portugal OVIDE section from 1993 to 2010, Prog. Oceanogr., 132, 250-261, https://doi.org/10.1016/j.pocean.2013.11.001, 2015.

Perez, F. F., Mouriño, C., Fraga, F., and Rios, A. F.: Displacement of water masses and remineralization rates off the Iberian Peninsula by nutrient anomalies, J. Mar. Res., 51, 869-892, https://doi.org/10.1357/0022240933223891, 1993.

Perez, F., Treguer, P., Branellec, P., García-Ibáñez, M. I., Lherminier, P., and Sarthou, G.: The 2014 Greenland-Portugal GEOVIDE bottle data (GO-SHIP A25 and GEOTRACES GA01), SEANOE, available at: http://doi.org/10.17882/54653, last access: 6 April 2018.

Pickart, R. S., Straneo, F., and Moore, G. K.: Is Labrador Sea Water formed in the Irminger basin?, Deep-Sea Res. Pt I, 50, 23-52, https://doi.org/10.1016/S0967-0637(02)00134-6, 2003.

Pickart, R. S., Torres, D. J., and Fratantoni, P. S.: The East Greenland Spill Jet, J. Phys. Oceanogr., 35, 1037-1053, https://doi.org/10.1175/JPO2734.1, 2005.

Piecuch, C. G., Ponte, R. M., Little, C. M., Buckley, M. W., and Fukumori, I.: Mechanisms underlying recent decadal changes in subpolar North Atlantic Ocean heat content, J. Geophys. Res.-Oceans, 122, 7181-7197, https://doi.org/10.1002/2017JC012845, 2017.

Piron, A., Thierry, V., Mercier, H., and Caniaux , G.: Gyre-scale deep convection in the subpolar North Atlantic Ocean during winter 2014-2015, Geophys. Res. Lett., 44, 1439-1447, https://doi.org/10.1002/2016GL071895, 2017.

Pollard, R. T., Grifftths, M. J., Cunningham, S. A., Read, J. F., Pérez, F. F., and Ríos, A. F.: Vivaldi 1991 - a study of the formation, circulation and ventilation of Eastern North Atlantic Central Water, Prog. Oceanogr., 37, 167-192, https://doi.org/10.1016/S0079-6611(96)00008-0, 1996. 
Pollard, R. T., Read, J. F., Holliday, N. P., and Leach, H.: Water masses and circulation pathways through the Iceland Basin during Vivaldi 1996, J. Geophys. Res., 109, C04004, https://doi.org/10.1029/2003JC002067, 2004.

Price, J. F. and Baringer, M. O.: Outflows and deep water production by marginal seas, Prog. Oceangr., 33, 161-200, https://doi.org/10.1016/0079-6611(94)90027-2, 1994.

Read, J. F.: CONVEX-91: water masses and circulation of the Northeast Atlantic subpolar gyre, Prog. Oceanogr., 48, 461-510, https://doi.org/10.1016/S0079-6611(01)00011-8, 2000.

Reid, J. L.: On the contribution of the Mediterranean Sea outflow to the Norwegian-Greenland Sea, Deep-Sea Res., 26, 1199-1223, https://doi.org/10.1016/0198-0149(79)90064-5, 1979.

Reid, J. L.: On the total geostrophic circulation of the North Atlantic Ocean: Flow patterns, tracers, and transports, Prog. Oceanogr., 33, 1-92, https://doi.org/10.1016/0079-6611(94)90014-0, 1994.

Rhein, M., Kieke, D., Hüttl-Kabus, S., Roessler, A., Mertens, C., Meissner, R., Klein, B., Böning, C. W., and Yashayaev, I.: Deep water formation, the subpolar gyre, and the meridional overturning circulation in the subpolar North Atlantic, Deep-Sea Res. Pt II, 58, 1819-1832, https://doi.org/10.1016/j.dsr2.2010.10.061, 2011.

Robson, J., Ortega, P., and Sutton, R.: A reversal of climatic trends in the North Atlantic since 2005, Nat. Geosci., 9, 513-518, https://doi.org/10.1038/ngeo2727, 2016.

Ross, C. K.: Temperature-salinity characteristics of the "overflow" water in Denmark Strait during "OVERFLOW'73", Rapports et Procès - verbaux des Réunions, Conseil Permanent International pour l'Exploration de la Mer 185, 111-119, 1984.

Rudels, B., Fahrbach, E., Meincke, J., Budéus, G., and Eriksson, P.: The East Greenland Current and its contribution to the Denmark Strait overflow, ICES J. Mar. Sci., 59, 1133-1154, https://doi.org/10.1006/jmsc.2002.1284, 2002.

Sarafanov, A., Falina, A., Mercier, H., Sokov, A., Lherminier, P., Gourcuff, C., Gladyshev, S., Gaillard, F., and Daniault N.: Mean full-depth summer circulation and transports at the northern periphery of the Atlantic Ocean in the 2000s, J. Geophys. Res., 117, C01014, https://doi.org/10.1029/2011JC007572, 2012.

Saunders, P. M.: The accuracy of measurements of salinity, oxygen and temperature in the deep ocean, J. Phys. Oceanogr., 16, 189-195, https://doi.org/10.1175/15200485(1986)016<0189:TAOMOS>2.0.CO;2, 1986.

Saunders, P. M.: The flux of dense cold overflow water southeast of Iceland, J. Phys. Oceanogr., 26, 85-95, https://doi.org/10.1175/15200485(1996)026<0085:TFODCO>2.0.CO;2, 1996

Saunders, P. M.: The dense northern overflows, in: Ocean Circulation and Climate, edited by: Siedler, G., Church, J., and Gould, J., Academic, New York, USA, 401-417, 2001.

SCOR Working Group: GEOTRACES - An international study of the global marine biogeochemical cycles of trace elements and their isotopes, Chem. Erde-Geochem., 67, 85-131, https://doi.org/10.1016/j.chemer.2007.02.001, 2007.

Takahashi, T., Broecker, W. S., and Langer, S.: Redfield ratio based on chemical data from isopycnal surfaces, J. Geophys. Res., 90, 6907-6924, https://doi.org/10.1029/JC090iC04p06907, 1985.

Tanhua, T., Olsson, K. A., and Jeansson, E.: Formation of Denmark Strait overflow water and its hydro- chemical composition, J. Marine Syst., 57, 264-288, https://doi.org/10.1016/j.jmarsys.2005.05.003, 2005.

Tanhua, T., Olsson, K. A., and Jeansson, E.: Tracer evidence of the origin and variability of Denmark Strait Overflow Water, in: Arctic-Subarctic Ocean Fluxes: Defining the Role of the Northern Seas in Climate, edited by: Dickson, R. R., Jens, M., and Rhines, P., Springer, Science and Business Media B.V., P.O. Box 17, AA Dordrecht, the Netherlands, 475-503, 2008.

Thierry, V., De Boisséson, E., and Mercier, H.: Interannual variability of the Subpolar Mode Water properties over the Reykjanes Ridge during 1990-2006, J. Geophys. Res., 113, C04016, https://doi.org/10.1029/2007JC004443, 2008.

Tomczak, M.: Some historical, theoretical and applied aspects of quantitative water mass analysis, J. Mar. Res., 57, 275-303, https://doi.org/10.1357/002224099321618227, 1999.

Tomczak, M. and Large, D. G. B.: Optimum Multiparameter Analysis of Mixing in the Thermocline of the Eastern Indian-Ocean, J. Geophys. Res.-Oceans, 94, 16141-16149, https://doi.org/10.1029/JC094iC11p16141, 1989.

Tsuchiya, M., Talley, L. D., and McCartney, M. S.: An eastern Atlantic section from Iceland southward across the equator, Deep-Sea Res., 39, 1885-1917, https://doi.org/10.1016/01980149(92)90004-D, 1992.

van Aken, H. M.: The hydrography of the mid-latitude northeast Atlantic Ocean I: the deep water masses, Deep-Sea Res. Pt I, 47, 757-788, https://doi.org/10.1016/S0967-0637(99)00092-8, 2000.

van Aken, H. M. and Becker, G.: Hydrography and through-flow in the northeastern North Atlantic Ocean: the NANSEN project, Prog. Oceanogr., 38, 297-346, https://doi.org/10.1016/S00796611(97)00005-0, 1996.

van Aken, H. M. and de Boer, C. J.: On the synoptic hydrography of intermediate and deep water masses in the Iceland Basin, Deep-Sea Res., 42, 165-189, https://doi.org/10.1016/09670637(94)00042-Q, 1995.

van Aken, H. M. and de Jong, M .F.: Hydrographic variability of Denmark Strait Overflow Water near Cape Farewell with multidecadal to weekly time scales, Deep-Sea Res. Pt I, 66, 41-50, https://doi.org/10.1016/j.dsr.2012.04.004, 2012.

Wüst, G. and Defant, A.: Atlas zur Schichtung und Zirkulation des Atlantischen Ozeans, Wissenschaftliche Ergebnisse: Deutsche Atlantische Expedition auf dem Forschungs- und Vermessungsschiff "Meteor" 1925-1927 6, Atlas, 103, 1936.

Xu, X., Schmitz Jr., W. J., Hurlburt, H. E., Hogan, P. J., and Chassignet, E. P.: Transport of Nordic Seas overflow water into and within the Irminger Sea: An eddy-resolving simulation and observations, J. Geophys. Res., 115, C12048, https://doi.org/10.1029/2010JC006351, 2010.

Yashayaev, I. and Dickson, R. R.: Transformation and fate of overflows in the Northern North Atlantic, in: Arctic-Subarctic Ocean Fluxes: Defining the Role of the Northern Seas in Climate, edited by: Dickson, R. R., Jens, M., and Rhines, P., Springer, Science and Business Media B.V., P.O. Box 17, AA Dordrecht, the Netherlands, 505-526, 2008.

Yashayaev, I. and Loder J. W.: Enhanced production of Labrador Sea Water in 2008, Geophys. Res. Lett., 36, L01606, https://doi.org/10.1029/2008GL036162, 2009. 
Yashayaev, I. and Loder J. W.: Further intensification of deep convection in the Labrador Sea in 2016, Geophys. Res. Lett., 44, 1429-1438, https://doi.org/10.1002/2016GL071668, 2017.

Yashayaev, I., Bersch, M., and van Aken, H. M.: Spreading of the Labrador Sea Water to the Irminger and Iceland basins, Geophys. Res. Lett., 34, L10602, https://doi.org/10.1029/2006GL028999, 2007.

Zou, S., Lozier, S., Zenk, W., Bower, A., and Johns, W.: Observed and modeled pathways of the Iceland Scotland Overflow Water in the eastern North Atlantic, Prog. Oceanogr., 159, 211-222, https://doi.org/10.1016/j.pocean.2017.10.003, 2017.
Zunino, P., Lherminier, P., Mercier, H., Daniault, N., García-Ibáñez, M. I., and Pérez, F. F.: The GEOVIDE cruise in May-June 2014 reveals an intense Meridional Overturning Circulation over a cold and fresh subpolar North Atlantic, Biogeosciences, 14, 5323-5342, https://doi.org/10.5194/bg-14-5323-2017, 2017. 